\title{
Hálózati hatások a belföldi migrációban
}

\author{
Németh Brigitta - Lőrincz László \\ https://doi.org/10.51624/SzocSzemle.2019.1.5 \\ Beérkezés: 2018.08. 27. \\ Átdolgozott változat beérkezése: 2019. 03.14. \\ Elfogadás: 2019.04.01.
}

\begin{abstract}
Összefoglaló: Kutatásunk a kapcsolathálók magyarországi vándorlásban játszott szerepével foglalkozik. A korábbi vizsgálatok elsősorban a nemzetközi vándorlásban mutatták ki a kapcsolathálók hatását a migrációra, tanulmányunkban ezt a belföldi migráció kapcsán elemezzük. Modellünkben a származási települések és a célhely-alternatívák infrastrukturális és gazdasági jellemzői mellett a hálózati hatások további push és pull faktorokként jelennek meg. Az elemzésbe bevontuk a települések jellemzőit a T-STAR adatbázis alapján, a települések közti távolságot pedig az útidővel jelöltük. A kapcsolathálók hatását az elmúlt évek vándorlásával és az iWiW közösségi hálón fenntartott kapcsolatokkal mértük. A longitudinális adataink a 2000-2014 közötti időszakra, a keresztmetszeti modellek pedig 2014-re vonatkoznak. A statisztikai elemzésekhez többszintủ (multilevel) és fixhatás modelleket használtunk. Eredményeink azt mutatják, hogy mind az elvándorlással, mind a letelepedéssel szignifikáns és pozitív összefüggésben vannak a kapcsolathálózati jellemző́k - mind a korábbi évek vándorlása, mind a közösségi hálón fenntartott kapcsolatok hatással vannak az aktuális évi vándorlás mértékére.
\end{abstract}

Kulcsszavak: belföldi migráció, kapcsolatháló, kumulatív okság, hálózati hatás, helyhasznosság, közösségi háló

\section{Bevezetés}

A mobilitás vagy vándorlás, valamint az azzal kapcsolatos társadalmi és gazdasági jelenségek már régóta a tudományos gondolkodás tárgyát képezik. A különböző elméletek a jelenség egy-egy aspektusát helyezik előtérbe. A munkaerőpiaccal, foglalkoztatottsággal és az iparszerkezeti sajátosságokkal, annak az egyes országok és területek közötti eltéréseivel - mint a migrációt alapvetően kiváltó strukturális okokkal - több elmélet is foglalkozik. Az egyén jövedelmi és fogyasztási lehetőségeinek maximális kihasználása, jólétének növelése szintén egy másik megközelítést ajánl a migrációs döntések vizsgálatához. Az ok-okozati és a vándorlást fenntartó folyamatok rendszere, a különböző, mikro-, makro-, mezoszintû perspektívák, a döntéshozási egység egyéni, családi vagy közösségi értelmezése megint másik fogalmi keretet kínál fel.

Egyéni szinten a célok, preferenciák, valamint az észlelt lehetôségek és korlátok mentén alakul ki a migrációs szándék. A megvalósításra egyéni erőforrások és „költség-haszon számítások" mellett a családi megfontolások, a kapcsolathálók, a gazda- 
sági, társadalmi, politikai körülmények és a munkaerőpiaci lehetőségek is hatással vannak (Blaskó-Gödri 2014).

A migráció hálózatelméleti megközelítésének hagyományában a legtöbb esetben a családi és ismeretségi kapcsolatok költségcsökkentő és hajlamosító szerepét vizsgálják. Például DaVanzo (1981) szerint a lakóhely-specifikus tőke és az információs költségek, tehát a kapcsolati tőke határozza meg az egyén migrációs hajlandóságát, vagy Deléchat (2001) a hálózat révén elérhető információk költség- és kockázatcsökkentő természetével foglalkozik. A migrációs folyamat másik pontja, amely elemzésénél szintén kifizetődő a kapcsolathálózati megközelítés, a letelepedés célpontjának kiválasztása. Nowotny és Pennerstorfer (2012) például azt vizsgálják, hogy milyen tényezők befolyásolják a gazdasági lehetőségeken és az intézményi adottságokon kívül a letelepedési hely kiválasztását.

Ezenkívül fontos a láncmigráció jelensége, ami szintén a vándorlók kapcsolathálózatain keresztül ragadható meg. Az egyén a kapcsolatainak egy részét fenntartja a költözés után is, így a vándorlása újabb kapcsolatokat hoz létre a származási és a letelepedési hely között, ez pedig további vándorlást indukálhat. A korábbi migrációból származó kapcsolatok egyébként hasznosak a betelepülőknek, főleg, ha ezek az ismerősök előnyös munkaerőpiaci helyzetben vannak. Azonban negatív hatással is járhat egy csoport azonos időszakban való nagymértékű beáramlása, mivel a munkaerőpiac telítődése ronthatja a csoporttagok elhelyezkedési esélyeit és a bérszínvonalat is (Beaman 2012). Ennek ellenére az eddigi modellek alapján úgy tűnik, hogy mind a korábbi vándorlás, mind a fennálló kapcsolatok pozitív hatást gyakorolnak a vándorlásra (Bauer-Epstein-Gang 2002).

A hálózatok szerepének vizsgálata a migrációban kihívást jelent a szükséges adatok területén. Az egyik lehetőség a kérdőíves adatgyűjtés - ekkor azonban fontos, hogy ne csak a bevándorlók egymással való kapcsolatait vizsgálhassuk, hanem őket össze lehessen hasonlítani azokkal, akik nem vándoroltak el a származási területükről. Ilyen jellegű komplex adatgyűjtésre példa a Mexican Migration Project 1995, melynek adatait használják például Munshi (2003), Deléchat (2001), valamint Bauer, Epstein és Gang (2002). Másik lehetőség több adatforrás egyesítése, amire kevés példa akad (pl. Deléchat 2001), vagy pedig az adminisztratív, aggregált adatok használata. Ennek során ki lehet használni viszont azt, hogy - kifejezetten a kapcsolatháló információközvetítő szerepe miatt - a betelepülők jellemzően nagy arányban választanak egy adott települést szemben más, hasonló jellemzőkkel bíró településekkel. Ahhoz viszont, hogy a kapcsolatháló és a korábbi vándorlás hatását egyszerre tudjuk tesztelni, idősoros adatokra van szükség. Így a korábbi vándorlás esetén a kapcsolatok információközvetítő jellegét feltételezhetjük, szemben az adott származási helyről érkezők arányának hatásával. Idősoros adatok esetén elkülöníthetjük továbbá a közelmúltbeli vándorlás hatását az összes bevándorló hatásától a két település (pl. Bauer-Epstein-Gang 2002; Beaman 2012) vagy két régió közti vándorlás adatai alapján (Nowotny-Pennerstorfer 2012). 
Megfigyelhető, hogy a korábbi kutatások elsősorban nemzetközi vándorlással foglalkoztak. Vizsgálatunkban a kapcsolathálók szerepét a belföldi vándorlás esetében vizsgáljuk, magyarországi települések között. Szerencsére hosszú idősorra vonatkozó adatokkal rendelkezünk a magyarországi települések közötti vándorlásról (a 2000-2014 közti éveket fogjuk elemezni). Emellett a települések közötti kapcsolatok sűrûségéről - szemben a korábbi kutatásokkal - közvetlen adatokat is bevonunk az elemzésbe, mégpedig az iWiW-adatbázis településszintre aggregált 2013-as adatainak felhasználásával.

A migrációs döntések place utility (helyhasznosság-) alapú vizsgálatában megkülönböztethetjük a küldő és a célterület jellemzőinek hatásait. A két komponenst azonban nem biztos, hogy ugyanazok a tényezők határozzák meg. A migrációs döntés folyamán ugyanis két elemet különböztethetünk meg (Wolpert 1965; Brown-Longbrake 1970), az egyik a migrációs hajlandóság, a másik pedig a letelepedés helyének kiválasztása. Így az elemzést is ennek megfelelően strukturáltuk, adataink segítségével lehetőségünk van mindkét esetben a kontextuális hatások vizsgálatára. A települések elhagyásával kapcsolatban azt elemezzük, hogy ha egy településnek relatíve több kifelé menő kapcsolata van, akkor igaz-e, hogy többen fognak elvándorolni? A célterület kiválasztása kapcsán pedig azt, hogy ha két település között erős a korábbi migrációs kapcsolat, vagy arányaiban sok a fenntartott kapcsolat, akkor az elvándorló nagyobb eséllyel választja-e azt a bizonyos települést más alternatívákhoz képest?

\section{Kapcsolódó elméletek és kutatások}

\section{A migráció közgazdasági megközelítései}

A migrációs áramlatok első modelljét, a push-pull elméletet Ravenstein (1889) fogalmazza meg. A fő megállapítása, hogy a potenciális elvándorlókat a célterületen elérhető lehetőségek bevándorlásra sarkallják, míg a korábbi lakhely kedvezőtlen körülményei kivándorlásra ösztönzik. A migráció volumenét és irányát e két tényező mellett a vándorlás távolsága határozza meg elmélete szerint. Dorigo és Tobler (1983) ezt úgy fogalmazzák meg, hogy push faktorok azok az élethelyzetek, melyek miatt az egyén elégedetlen az aktuális lakóhelyével, a pull faktorok pedig azok a tulajdonságai a célhelynek, melyek miatt az vonzónak tűnik. A két település közti távolság megadható kilométerben, útidőben, útköltségben, társadalmi távolságban vagy munkalehetőségekben is. Brown és Longbrake (1970) a migrációs folyamatot kifejezetten két fázisba sorolják: (1) az új lakóhely keresésére vonatkozó döntés, és (2) az alternatív helyek közötti döntés az összehasonlított helyhasznosságuk alapján. Ez felhívja a figyelmet a migrációnak arra az aspektusára, hogy az elvándorlásra és a célhely kiválasztására vonatkozó döntést befolyásoló tényezők eltérhetnek egymástól (Sell - DeJong 1978) .

A neoklasszikus közgazdaságtan elméletei szerint a migráció a munkaerő globális keresletének és kínálatának kiegyenlítődését célzó mechanizmus. Azokból az 
országokból, ahol jelentős munkaerőtöbblet van és a bérszínvonal alacsony, a bérkülönbségek hatására a munkások a magasabb bért kínáló helyekre települnek. Ennek eredményeként a kibocsátó területeken a munkaerő-felesleg csökken, a bérek is emelkedni kezdenek, a befogadó területeken pedig ezzel ellentétes tendenciák érvényesülnek. Ez a kiegyenlítődés az elmélet szerint egy egyensúlyi állapot kialakulásáig tart. Ezzel ellentétben Harris és Todaro (1970) kétszektoros modelljükben bemutatják, hogy ha a dolgozók a várható jövedelem alapján döntenek a vidékről városokba költözésről, akkor - amíg a városi bérek magasabbak a vidékinél - jelentős migráció indul meg a városok felé, ami ott munkanélküliséget okoz.

A történeti strukturális iskolához tartozó szegmentált munkapiac elmélete (Piore 1979) szerint a háború után gyorsan fejlődő nyugat-európai országokban létezik egy primer és egy szekunder munkaerőpiac. Az első jól fizető állásokkal, erős érdekképviselettel rendelkező, biztonságos piac. Ettől elkülönülve létezik egy szekunder munkaerőpiac is, ahol rosszabb munkakörülmények, alacsonyabb kereseti lehetőség érhetőek el, viszont nincs, vagy könnyen teljesíthető a belépési küszöb, így a bevándorlók széles tömegei számára is nyitva áll (Hagen-Zanker 2008).

A makrogazdasági modellekhez hasonlóan a mikrogazdasági modellek is az egyén migrációs döntésére épülnek. Az egyén - racionális cselekvőnek feltételezve - akkor dönt a migráció mellett, ha az nettó hasznot hoz, vagyis a költségeket levonva is nyereséges (gazdasági, pszichológiai tényezőket is figyelembe véve). Sjaastad (1962) a migrációt mint az egyensúly irányába ható mechanizmust vizsgálja, és erőforrás-allokációs keretbe helyezi. Mivel a migráció erőforrásokat igénylő tevékenység is egyben, a cél a migrációs beruházások megtérülésének a meghatározása. Az egyéni költségeket pénzbeli és nem pénzbeli költségekre bontja; az előbbiek közé tartoznak a költözés anyagi terhei, míg az utóbbiak magukban foglalják a megváltozott környezet „pszichés” költségeit. A migráció megtérülése a nominális jövedelem változásából, a foglalkoztatás költségeinek változásából, az árak változásából vagy e három kombinációjából ered. Az így meghatározott pénzkészletek pedig eléggé általánosak ahhoz, hogy nem csak a lakóhelyváltás révén elért jövedelemkülönbségből eredő megtérüléseket, hanem az áttelepülő fogyasztói minőségében elért eredményeket is magukban foglalják.

A migráció új közgazdaságtana elsősorban azzal hoz újdonságot, hogy a migrációs döntéseket nem egyének, hanem családok, közösségek szintjén magyarázza. Itt a kockázatok minimalizálása jelenik meg elsődleges szempontként. A migráció nem egyszerúen a család jövedelmének növelésére szolgál, hanem hozzájárul a jövedelemforrások diverzifikációjához is. Azt az összefüggést állapítja meg, hogy a tudományos elemzéshez a családokra, háztartásokra vagy más, kulturálisan meghatározható, termelési és fogyasztási egységekre kell támaszkodni, nem pedig az elszigetelt egyénre. Stark és Bloom (1985) ezt a folyamatot úgy definiálják, hogy a migrációkutatás kiterjesztette azon változók tartományát, amelyek a térbeli munkaerő-eloszlási döntésekre hatással vannak. Az elmélet rámutat a szélesebb társadal- 
mi jelenségek és interakciók szerepére a migrációs magatartás meghatározásában. A referenciacsoporton belüli relatív helyzet értelmezése például pszichés költségeket vagy előnyöket - a relatív depriváció vagy relatív elégedettség érzéseit eredményezi. Egy személy áttelepülését pedig meghatározhatja a relatív pozíció vagy a referenciacsoport megváltoztatásának törekvése is. A vándorlásra vonatkozó döntéseket tehát gyakran az áttelepülő és a nem áttelepülők csoportja közösen hozza meg, valamint a költségeket és a megtérüléseket is megosztják.

A migrációs vizsgálatok egyik legáltalánosabb következtetése az életkor és a migráció közötti kapcsolat. Számos életciklus-esemény lehet fontos az egyén vagy egy család migrációs döntésében. Ilyen a házasság, válás, gyermekvállalás, vagy a gyermekek leválása, tanulmányok befejezése, nyugdíjazás. Más egyéni jellemzők, amelyek szintén gyakran életciklusokhoz kapcsolódnak, szintén fontosak lehetnek. Ilyenek a munkapiaci státusz, kereset, tanulmányok, a megszerzett készségek és képzettség, életkor, nem, egészségi állapot (Greenwood 1997). Migráció gyakran fordul elő ezeknek az életciklusoknak a váltásakor, mivel megváltozik az egyén vagy család szükséglet- és lehetőségstruktúrája, ennek nyomán a lakóhely költség-haszon vonzata. A fiatalabb életkorokban jellemzően nagyobb a realizálható haszon, az idősebb életkorokban viszont inkább a ráfordításoldal (a költözéssel járó kellemetlenségek) növekszik.

A fiatalok (férfiak és nők is) könnyebben változtatnak lakóhelyet, mint az idősek. Az ilyen vándorlás költsége az emberi beruházás egy formáját képezi. A fiatalabbak számára több év áll rendelkezésre, amely alatt realizálhatják az ilyen jellegú beruházást. Ennélfogva a kisebb bérkülönbség is gazdaságilag előnyössé teszi számukra a költözést - a fiatalok a vándorlásba való beruházásból magasabb járadékra számíthatnak, mint az idősebbek. Ez a különbség magyarázhatja meg a szelektív vándorlást anélkül, hogy a fiatalok és az idősek közötti szociológiai különbségeket vizsgálnánk (Schultz 1983).

Clark és Hunter (1992) az Egyesült Államok megyéi 1970-1980 közti nettó vándorlásának adatain az emberi tőke, a közjavak és az elérhető szolgáltatások összefüggéseit vizsgálták az életkor-specifikus migrációval kapcsolatban. Azt találták, hogy a munkalehetőségek, az adópolitika és a szolgáltatások is az életciklustól függően gyakorolnak hatást a vándorlásra. A kereseti lehetőségek leginkább az aktív korú férfiak számára, a szolgáltatások pedig a középkorú és idősebb férfiak számára fontosak. A fiskális környezet hatása szintén összefügg az életkorral, a legmagasabb keresetű életkorban a férfiak elkerülik a magas jövedelemadót meghatározó közigazgatást, és ez a későbbi életkorokban is így marad; nem preferálják a magas örökösödési vagy ingatlanadót megállapító megyéket.

\section{A kapcsolathálók szerepe a migrációban}

Az 1980-as évektől - elsősorban az amerikai és nyugat-európai szakirodalomban megjelenik a kapcsolathálóknak és a bennük rejlő kapcsolati tőke szerepének vizsgálata a migrációs folyamatok különböző szakaszaiban (Boyd 1989). DaVanzo (1981) 
szerint a lakóhely-specifikus tőke és az információs költségek mentén a kapcsolati tőke határozza meg az egyén migrációs hajlandóságát.

A kapcsolathálózatok jelentősége arra vezethető vissza, hogy a migráció során az emberek számos költséggel szembesülnek azzal kapcsolatban, hogy hogyan tájékozódjanak, milyen módon lehet munkához jutni, stb. - a kapcsolatokon keresztül megszerezhetők ezek az értékes információk, így csökkentik a migrációval járó költségeket és kockázatokat. Emiatt a családban vagy a közösségben meglévő migrációs tapasztalat befolyásolja az egyének migrációs döntéseit (Massey et al. 1993; Deléchat 2001).

Az elemzések emellett rávilágítanak arra, hogy a kapcsolathálók hatása már a potenciális elvándorlók kiválasztódásában is érvényesül. Az információk és az általuk elérhető erőforrások befolyásolják a migrációs döntést, hosszú távon pedig a kapcsolathálók tartják múködésben a küldő és fogadó ország közötti vándormozgalmakat. Egyéni szinten nagyobb valószínüséggel vándorolnak ki azok, akik rendelkeznek kapcsolatokkal az adott célországban; közösségi szinten pedig gyakoribb a migráció ott, ahol a közösségből már sokan kivándoroltak, vagy rendelkeznek migrációs tapasztalattal. A kapcsolathálóknak ezen túlmenően nemcsak a migráció kibontakozásában és fenntartásában van szerepük, hanem a bevándorlók fogadó országbeli kezdeti adaptációját és hosszú távú beilleszkedését is meghatározzák (Hautzinger-Hegedűs-Klenner 2014).

Haug (2008) a közösségi és rokonsági kapcsolatokat push és pull tényezőként értelmezi. Arra az eredményre jut, hogy a lakóhelyen fennálló kapcsolatok az elvándorlás ellenében hatnak, mivel az erős közösségi kötődés, az abba való befektetések csökkentik a migrációs hajlandóságot; a letelepedés helyén fennálló kapcsolatok pedig a célhely pull faktoraként hatnak az információáramlás és a relokáció utáni beilleszkedés segítése révén.

Kutatásunk során azt feltételezzük, hogy ez a hatás a belföldi migráció esetében is fennáll.

Feltételezzük, hogy a kiterjedt külső kapcsolathálóval rendelkezô településekrôl nagyobb arányban vándorolnak el, mint onnan, ahol a kapcsolatok nagyobb része a településen belül áll fenn (H1/a).

A kumulatív oksági hatás elmélete szerint a migrációra jellemző, hogy egyrészt egyre elterjedtebbé válik, másrészt az is, hogy a demográfiai, társadalmi és gazdasági bázisa szintén kiszélesedik. Ez elméletileg abból fakad Massey és munkatársai (1993) szerint, hogy a migráció úgy befolyásolja a személyes motivációkat és a társadalmi struktúrát is, hogy ösztönzi a további vándorlást. İgy a migráció öngerjesztő folyamattá válik, és egyre inkább függetlenedik azoktól a feltételektől, melyek eredetileg kiváltották. Eszerint a kezdeti vándorlás után a további mozgások valószínúsége az időben előrehaladva is nő. Ebben a kapcsolathálók önfenntartó természete mellett további tényezők is szerepet játszanak. A kutatások alapján hat olyan társadalmi-gazdasági tényező azonosítható, amelyek potenciálisan hatást gyakorolnak a 
migrációra ilyen kumulált formában: a jövedelemeloszlás, a föld eloszlása, a mezőgazdasági termelés szerkezete, a migráció kultúrája, a humán tőke regionális eloszlása és a munka társadalmi címkézése (Massey et al. 1993, 1994).

Abban az esetben tehát, ha egy településről jelentős az elvándorlás, akkor az öngerjesztővé válhat e mechanizmusokon keresztül. A korábban elköltözöttek fenntartják a kapcsolatot a még otthon maradottakkal, emiatt nő a külső kapcsolatok aránya az ottmaradók körében. E kapcsolatokon keresztül az elköltözők megoszthatják tapasztalataikat az ottmaradókkal, csökkentve a „vándorlási befektetés” bizonytalanságát. Hosszú távon egyfajta migrációs kultúra (Gyáni 2003) alakulhat ki, szemben a helyben maradás és helyben érvényesülés alternatívájával. Emiatt a belföldi vándorlás kapcsán azt feltételezzük, hogy nem csak a külső kapcsolatok aránya, de a múltbeli vándorlás is összefügg az elvándorlás valószínűségével.

Azokon a településeken, ahol magas a korábbi évek elvándorlási aránya, magas lesz az adott évi elvándorlás aránya is $(\mathrm{H} 1 / b)$.

A kapcsolathálók fontos szerepe, hogy nem csak a migrációról általában biztosítanak információt, hanem számos praktikus tapasztalattal szolgálnak a konkrét településekről is. Az egyik leglényegesebb ezek közül, hogy az ismerősök segíthetik a letelepedőt a munkaerőpiacon megfelelő állást találni. Ezzel kapcsolatban Beaman (2012) az Egyesült Államok városaiban élő különböző etnikai hátterű bevándorlók esetében azt találja, hogy ha a hálózat tagjainak száma megnő rövid távon (az azonos évben vagy az előző évben letelepedettek között), akkor romlanak a munkaerőpiaci esélyek. Ezzel szemben, ha a hálózatban az érkezés időpontjában nagyszámú korábban letelepedett, foglalkoztatott munkavállaló van, akkor az újonnan letelepültek elhelyezkedési valószínűsége nő. Kutatásában ezzel arra mutat rá, hogy nem csak a kapcsolatháló mérete, de tulajdonképpen a „minősége” is meghatározó az elérhető nyereségek szempontjából.

Nowotny és Pennerstorfer (2012) azt vizsgálják az európai régiókban, hogy a migráció célpontjának kiválasztását milyen tényezők befolyásolják a gazdasági lehetőségeken és az intézményi adottságokon kívül. Eredményeik azt mutatják, hogy az etnikai hálózat mérete kifejezetten fontos szempont a letelepedés helyének megválasztásakor, és a bevándorlók csak komoly anyagi kompenzáció esetén hajlandóak olyan helyre költözni, ahol a saját etnikumuk még nincs képviselve, vagy csak kisebb mértékben.

Ebből adódik a következő, a letelepedés helyének kiválasztására vonatkozó hipotézisünk:

H2/a: Egy településröl inkább azokra a településekre vándorolnak az emberek, amelynek lakóival több kapcsolattal rendelkeznek.

Bauer, Epstein és Gang (2002) arra tesznek kísérletet, hogy a hálózati hatást elkülönítsék a nyájhatástól. A hálózati hatással szemben nyájhatásnak nevezik a korábbi évek migrációjának hatását, és arra számítanak, hogy a kapcsolathálón keresztül elérhető információk naprakészek, így az adott helyen addig folytatódik a bevándorlók 
letelepedése, amíg az ott élők körülményei valóban jók (tehát a bevándorló profitál a hálózatból). Ezzel szemben a nyájhatás nem ilyen pontos információk alapján érvényesül, így a migráció akkor is fennmarad, amikor a további bevándorlás már rontja a kilátásokat. A szerzők feltételezése szerint a két hatás egyszerre is létezik, számítanak ezek interakciójára. Eredményeik azt mutatják, hogy a mexikóiak aránya a település népességén belül összefüggést mutat azzal, hogy mekkora valószínűséggel választják további mexikói bevándorlók azt a települést letelepedésük célpontjául. A hatás fordított U alakú mintázatot ad, és az etnikum 10\%-os részarányánál van a csúcspontja - a hálózati hatás a népességen belüli 10\%-os arányig vonzza az újabb bevándorlókat. Emellett érvényesül a nyájhatás, vagyis megelőző évi 1\%-os emelkedés a településen letelepedők számában 0,53\%-kal növeli adott évben a település kiválasztásának valószínűségét egy következő bevándorló döntésében. A migráció önfenntartó természete tehát különböző visszacsatolási mechanizmusok révén jut érvényre.

A letelepedés helyének kiválasztását a fenti két, egymástól különböző, de párhuzamosan múködő mechanizmus is befolyásolja, melyek ugyanabba az irányba hatnak. E probléma mentén a következő hipotézist adjuk hozzá a letelepedés helyének kiválasztásával foglalkozó modellhez:

H2/b: A korábbi évek nagymértékü vándorlása két település viszonylatában nagyobb mértékü vándorlást valószinüsít a következö évben is.

A kapcsolathálók szerepe nem feltétlenül egyezik meg minden demográfiai csoportban. Például Oldakowski és Roseman (1986) kutatásának eredményei is jelentős változást mutatnak a migrációs szándékra vonatkozóan az életciklus során. Kutatásukban a származási településen belüli kapcsolatok két csoportban voltak fontosak, a fiatalok és az idős felnőttek esetében - míg a nyugdíjazás előtt állók korcsoportjában a személyes jellemzők voltak a legmeghatározóbbak a vándorlási szándékkal való összefüggésben.

\section{A kapcsolatok online fenntartása}

A közösségi oldalak támogatják mind a meglévő kapcsolatok fenntartását, mind új kapcsolatok kialakítását. Manapság az ismeretségek a hagyományos lehetőségek mellett online is fenntarthatók, továbbá az online színtéren felhalmozódnak az egyébként mozgósítható, de aktuálisan nem élő kapcsolatok is.

A kapcsolatok online fenntartása kapcsán az egyik legelső eredmény Hampton és Wellman (2001) kutatása. Egy újonnan épült kanadai elővárosba költöző lakók körében vizsgálták a kapcsolatok változását úgy, hogy az új lakók egy része számára széles sávú internetet biztosítottak. Azt találták, hogy a költözés kapcsán visszaesés volt megfigyelhető a kapcsolatok fenntartásában azoknál a lakóknál, akik nem rendelkeztek széles sávú internettel, míg a másik csoportban nem történt ilyen. A kapcsolatok távolságát tekintve a visszaesés elsősorban a közepes (50-500 km) és a nagy (500 km feletti) távolságú kapcsolatokat érintette. 
Ellison, Steinfield és Lampe (2007) a közösségi hálókon fenntartott kapcsolatokban rejlő társadalmi tőke sajátosságaival foglalkoznak. Az irodalom különbséget tesz összekötő (bridging) és összetartó (bonding) típusú társadalmi tőke közt. Ehhez adnak a szerzők egy új dimenziót, a fenntartott társadalmi tőke kategóriáját. Ez azt a képességet írja le, hogy az egyének az internet segítségével mennyire képesek értékes kapcsolatokat megőrizni életciklusokon át.

Brooks és munkatársai (2014) a Facebook-aktivitás és a társadalmi tőke összefüggéseit vizsgálják. Azt találják, hogy a kapcsolatfenntartó és az információkereső magatartások a közösségi oldalon pozitív összefüggést mutatnak a társadalmi tőke érzékelt mértékével, míg az ismeretségi hálózat tranzitivitása negatívan korrelált az összetartó társadalmi tőkével.

Mivel a kapcsolati tőke felhalmozásának egyik fontos színtere tehát a közösségi média (Ellison-Steinfield-Lampe 2007), így feltételezhetjük, hogy a településen belüli, illetve egyes települések közötti kapcsolatok sűrűsége mérhető a közösségi oldalakon fennálló kapcsolatok segítségével. Ehhez az iWiW közösségi oldal adatait fogjuk használni. Az iWiW magyar alapítású közösségi oldal volt, melyet 2002-ben alapítottak, és 2010-ig a legnépszerúbb online közösségi hálózat volt Magyarországon. 2009-re az oldalnak több mint 3,5 millió aktív felhasználója volt, ami akkor az összes internethasználó körülbelül kétharmadát jelentette. Az iWiW-en fel lehetett venni a kapcsolatot iskolatársakkal, munkatársakkal, ismerősökkel, ismerősök ismerőseivel, barátokkal, családtagokkal stb. Ezek a kapcsolatok az offline közösség felbomlása, elhagyása, vagy az ismeretség jelentőségének elkopása esetén is fennmaradnak a közösségi hálón (kivéve persze, ha valamelyik fél kifejezetten megszakítja a kapcsolatot a másik féllel, de ez ritka). Így továbbra is lehetőség van az ismerősök követésére, az ismerősöktől vagy ismerősökről való információ szerzésére.

\section{A magyarországi migráció föbb strukturális és demográfiai jellemzôi}

Egy ország népességének térbeli eloszlása nagyban függ a gazdasági és politikai berendezkedéstől. A kelet-európai társadalmak posztszocialista átmenete a népességük eloszlására is hatást gyakorolt, így az 1990-es évek magyarországi népességvándorlását nagyrészt az ipari és mezőgazdasági termelés struktúrájának megváltozása befolyásolta. Két fő migrációs tendencia bontakozott ki 1990 után Magyarországon. Az egyik a városok körüli agglomerációk irányába ható szuburbanizációs folyamat, a másik pedig egy ennél enyhébb, de így is jelentős áramlat: a vidéki periféria irányába vándorló elbocsátott városi munkásoké (Brown-Schafft 2002).

Dövényi (2009) szerint az ország népességszerkezetére erőteljes hatást gyakorolt emellett két másik tényező is. Az egyik, hogy napjainkra a természetes szaporodást felmutató települések köre jelentősen lecsökkent, a másik pedig, hogy a térségek népességszámának alakulását lényegesen befolyásolja a vándorlás. Mindenképpen hátrányos helyzetben vannak utóbbi szempontból azok a települések, ahol a munkanélküliek aránya érzékelhetően meghaladja az országos átlagot. Borsod-Abaúj- 
Zemplén és Szabolcs-Szatmár-Bereg megyében a kistérségek szinte kivétel nélkül ebbe a kategóriába tartoznak, így ezekről a területekről jellemző az elvándorlás.

Bálint és Gödri (2015) a belföldi migráció demográfiai sajátosságairól azt írják, hogy míg a kilencvenes években a 15-29 évesek vándorlási rátája volt a legnagyobb, a 2000-es évek második felében már a 0-14 éves és a 30-44 éves korcsoportokban is hasonló léptékű migráció volt tapasztalható, ami a fiatal, kisgyermekes családok mobilitásának növekedésére utal. A vándorlási távolságot illetően az ezredfordulóig csökkenő, majd növekvő trend volt a jellemző. Az állandó vándorlások átlagos távolsága 50-55 km volt, de a vándorló népesség fele ennél jóval rövidebb, 21-23km távolságon belül költözött. A belföldi vándorlásban jellemző férfitöbbletet 1993-ban felváltja a nők kisebb túlsúlya, ami leginkább az ideiglenes vándorlásokból adódik (Gödri-Spéder 2009).

$\mathrm{Az}$ ezredfordulót követően a belföldi vándorlás elsősorban a közép-magyarországi régió, főleg Budapest felé irányult. A legnagyobb népességátrendeződés 2007ben volt, a központi régiónak a keleti országrésszel szemben 11 ezer fős, a nyugati országrésszel szemben pedig 4 ezer fős nyeresége volt a belföldi vándorlásból. A Közép-Dunántúl 2009-től kezdve elvesztette korábbi vándorlási többletét. Budapestet - az 1991 és 2008 közötti negatív vándorlási egyenlege után - 2009-től újra vándorlási többlet jellemzi. A 2010-től 2013-ig terjedő időszakban a fővároson kívül Győr-Moson-Sopron, Vas, Fejér és Pest megyékben volt pozitív az állandó vándorlási egyenleg, a Dunától keletre eső megyékre kivétel nélkül a vándorlási veszteség volt jellemző. A belföldi vándorlásból adódó legnagyobb veszteséget ezek alapján az eredmények alapján is Észak-Magyarország és az Észak-Alföld szenvedi el (BálintGödri 2015).

\section{Adatok és módszertan}

\section{Adatok}

Az elemzés négy adatbázisra támaszkodik, és a metszetükre, a 2000-2014 közötti időszakra vonatkozik. A települések közötti vándorlásról a Központi Statisztikai Hivatal 1975 és 2014 közötti belföldi vándorlásra vonatkozó adatbázisa szolgáltatja az adatokat, melyhez a KSH kutatószobájában fértünk hozzá. Ez arról tartalmaz információt, hogy az adott időszakban az új lakcímigényléseket melyik évben, melyik hónapban milyen korú, nemű, családi állapotú személy kezdeményezi, és melyik településről melyik településre jelentkezik át ideiglenes vagy állandó lakcím létesítésekor. Az adatbázisban tehát nem azonosítható a vándorló személye, és az sem, hogy az adott személy ideiglenes lakcím igénylésekor például hol rendelkezik állandó lakcímmel.

A második adatforrást az iWiW közösségi oldal kapcsolathálózati adatai jelentik. A közösségi oldal összes felhasználójának adatait (belépés dátuma, nem, életkor, 
lakóhely) és a köztük lévő kapcsolatokat a szolgáltató 2013-ban archiválta, és tette elérhetővé kutatási célra az OTKA K-112713 „The life-cycle of an Online Social Network" kutatási projektben. Kutatásunkhoz az egyéni kapcsolatokat tartalmazó adatbázis település-település, illetve település-demográfiai csoport szintre aggregált változatát használtuk.

A harmadik fő adatbázis a KSH T-Star adatbázisa. Ez egy településstatisztikai adatbázisrendszer, amely az ország valamennyi településére településstatisztikai szemszögből gyűjti egybe a legfontosabb számszerű információkat, idősorrendben és témacsoportonként rendszerezve az 1990 és 2015 közötti időszakra vonatkozóan. 22 változót választottunk ki a települések infrastruktúrájának, munkaerőpiaci, gazdasági jellemzőinek a leírására. Az elemzésbe való bevonáshoz ezeket a változókat főkomponens-elemzéssel 6 faktorba vontuk össze. Így például az első faktor (1: Városi közszolgáltatások) a településeken az egy főre eső kiskereskedelmi boltok számának logaritmusát, az egy főre eső vendéglátóhelyek számának logaritmusát, az egy főre eső kórházi ágyak számának logaritmusát, az egy főre eső bölcsődei férőhelyek számát és a múzeum létére vonatkozó dummy változót foglalja magában. Ehhez képest például külön faktorba (4: Alapvető közszolgáltatások) kerültek az egy főre eső általános iskolai és óvodai férőhelyek, illetve a háziorvosok száma (bővebben a Mellékletben).

Negyedikként az MTA KRTK Adatbank által készített „KÖZÚT” adatbázisból a települések közti (személygépkocsival, közúton megtett út) útidőt használjuk a települések közti távolság mérésére. Az adatbázisban 2000, 2005, 2010, 2013 és 2014 évek adatai szerepelnek. Az elemzésben 2005-ig a 2000-ben mért időt használjuk, 2010-ig pedig a 2005-ben mértet, és így tovább.

\section{Változók és elemzési módszerek}

\section{A település elhagyásának modellezése}

A települések elhagyását meghatározó tényezőket vizsgáló modellben azt szeretnénk számszerúsíteni, hogy az adott településről történő elköltözés valószínűsége hogyan függ össze a korábbi évek migrációjával és az iWiW-en fenntartott kapcsolatokkal. Ismert, hogy a migrációs hajlandóság lényegesen különböző az egyes demográfiai csoportokban, ezért az elemzést demográfiai csoportonként végezzük el. Függó változónk ennek megfelelően az elköltözők korcsoport- és nemspecifikus éves vándorlási aránya (tehát adott településről adott évben demográfiai csoportonként az elvándorlók aránya a csoportjuk teljes népességéhez képest).

A migrációs hajlandóság az irodalom alapján nem- és életciklus-specifikus jelenség (Schultz 1983; Oldakowski-Roseman 1986; (Clark-Hunter 1992); Greenwod 1997), ezért megkülönböztetünk az elemzés során 14 demográfiai csoportot (nem és korcsoport alapján). Az első korcsoportba a 15 év alattiak kerültek, a másodikba 
a 15-19 évesek, a harmadikba a 20-29 évesek, a negyedikbe a 30-39 évesek, az ötödikbe a 40-49 évesek, a hatodikba az 50-59 közöttiek és a hetedik a 60 év felettieké.

Az elemzés során nem elhanyagolható a kiindulási település, mivel a származási település és a célhely közti kapcsolatok határozhatják meg a célhely népszerűségét a többi viszonylathoz képest. Szerepet játszik emellett a távolság (feltételezve migrációs vonzáskörzeteket például regionális központok esetében, stb.).

A hálózati hatásokkal kapcsolatos előfeltevés szerint a sok külső kapcsolat erősíti a migrációs hajlandóságot (H1/a). E hipotézis vizsgálatához az iWiW-adatbázisból a településeken élők külső (más településeken élő felhasználókkal fennálló) kapcsolatainak arányát használjuk az összes (településen belüli és a más településen élő felhasználókkal fenntartott) kapcsolatukhoz képest.

A kumulatív okság (Massey et al. 1993, 1994) feltevésének (H1/b) tesztelésére a településeken az adott demográfiai csoport elvándorlási arányának a megelőző 2 évre vonatkozó átlagát használjuk. Elképzelhető azonban, hogy ez a hatás nem csak az adott demográfiai csoporton belül létezik, hanem a településen általánosságban. Ezért az elvándorlási arány elmúlt kétéves átlagát a teljes településre vonatkozóan is bevonjuk az elemzésbe.

A hálózati hatások mellett fontos befolyásoló tényezőt jelentenek a település infrastrukturális és gazdasági adottságai és az elérhető szolgáltatások. E tényezőket kontrollváltozókként szerepeltetjük a modellben, melyeket a T-Star adatbázis alapján hoztunk létre főkomponens-elemzéssel. A változók és a főkomponens-elemzés leírását a Melléklet tartalmazza.

A migrációs kultúrával kapcsolatos H1/b hipotézis tesztelésére ennek megfelelően a következő regressziós modellt alkalmazzuk:

$\frac{M_{\text {iast }}}{P_{\text {iast }}}=\alpha+\boldsymbol{\beta}_{1} \boldsymbol{f}_{i, t-1}+\beta_{2} k_{\text {iast }}+\beta_{3} k_{i t}+\boldsymbol{\gamma} \boldsymbol{D}_{\text {ias }}+\varepsilon_{i a s t}+\xi_{i t}$,

ahol $M$ = migráció, „i” településről „a” korcsoportban „s” nemű elköltözők „t” évi száma, $P$ a lakónépesség száma. „f” a települések adottságaira vonatkozó faktorok, „k” a korábbi két év átlagos elvándorlási aránya $\left(k_{\text {iast }}=\frac{M_{\text {ias }, t-1}+M_{\text {ias }, t-2}}{p_{\text {ias }, t-1}+p_{\text {ias }, t-2}}, D_{\text {ias }}\right.$ pedig a demográfiai csoportok kétértékú változói. $\varepsilon_{i j t}$ és $\xi_{i j}$ a hibatagok.

Tekintve, hogy a magyarázó változók között vannak olyanok, melyeket település-év, és olyanok is, melyeket település-év-demográfiai csoport szinten figyelünk meg, a becsléshez többszintű regressziós modellt használunk. ${ }^{1}$

Megjegyzendő továbbá, hogy modellünkben, bár több év adatait elemezzük, nem fixhatás-panel identifikációt alkalmazunk, hanem keresztmetszetit (pooled cross section) - nincsenek ugyanis a modellben a település-év dummyk. Fixhatás-panel modell becslése esetén ugyanis a $\beta_{3}$ paraméter értelmezése a következő lenne: abban az esetben, ha egy adott településről a megelőző években nagyobb volt az elvándorlás,

1 Az elemzést a Stata szoftver „meglm” parancsával végeztük. 
e településen a következő évben is nagyobb elvándorlást várhatunk. Míg a pooled cross section esetén ez: azokon a településeken, ahol nagyobb elvándorlást figyelhettünk meg az előző években, ott a következőben is nagyobb elvándorlást várhatunk a hasonló jellemzőkkel bíró településekhez képest. Véleményünk szerint a kumulatív okságra vonatkozó elméleti hipotézisünknek egyértelmúen ez utóbbi felel meg.

A kapcsolatok számára vonatkozó H1/a hipotézis vizsgálata hasonlóképpen történik, azzal a különbséggel, hogy ott csak egy év adatait tudjuk használni. Ennek oka az, hogy a fő magyarázó változónk - a külső kapcsolatok aránya az iWiW-en - hosszabb időtávon nem jó proxy a településen élők külső kapcsolatainak a leírására. Mivel ha az iWiW-es külső kapcsolatok arányát egy adott településen az idő folyamán vizsgálnánk, az feltételezhetően a közösségi háló „divatjának” terjedését modellezné, és nem a lakók külső kapcsolatainak változását. Tekintve, hogy az iWiW először Budapesten vált népszerúvé és onnan terjedt el a nagyvárosokra majd a kisebb településekre, és a hálózat elhagyása is hasonló dinamikát mutat (Lengyel et al. 2018).

Itt is kétszintű adatbázisról van szó, a települések jellemzőit leíró faktorokat településszinten, a vándorlás és a közösségi oldal adatait település-demográfiai csoport szintjén mértük.

$\frac{M_{i a s}}{P_{i a s}}=\alpha+\boldsymbol{\beta}_{1} \boldsymbol{f}_{i}+\beta_{2} k_{i a s}+\beta_{3} c_{i a s}+\boldsymbol{\gamma} \boldsymbol{D}_{i a s}+\varepsilon_{i a s}+\xi_{i}$

A fő magyarázó változó ebben az esetben a „c” - az iWiW közösségi oldalon a külső és az összes kapcsolat aránya a demográfiai csoportokon belül az adott településen, kontrollváltozóként a H1/b hipotézisre vonatkozó „megelőző két év átlagos elvándorlási aránya" változó ( $k$ ) is szerepel. A keresztmetszeti elemzés a 2014-es évre vonatkozik, azonban az endogenitás elkerülése érdekében a fő magyarázó változóink az iWiW-es kapcsolatok (c) és a faktorok ( $f$ ) esetében is a megelőző év adatai (2013).

\section{A letelepedés helyének kiválasztása}

A letelepedés helyének vizsgálata során a függő változónk településpárra vonatkozik: a két település közti, adott irányú migráció nagysága a küldő település összes elvándorlójának a számához viszonyítva.

A közösségi háló segítségével mért kapcsolati sűrűségnek a letelepedési hely kiválasztására gyakorolt hatásával kapcsolatban az a feltételezésünk, hogy a két település közti sûrử kapcsolatháló népszerúvé teszi az adott viszonylatot az elvándorlók körében (H2/a). Ennek mérésére az adott évben a két település közt az iWiW-en fennálló kapcsolatok számát viszonyítjuk a többi településsel fenntartott kapcsolatok számához. 
Az előző évek vándorlásának a hatását (H2/b) a megelőző 2 év migrációjának segítségével mérjük küldő és fogadó település között, a többi viszonylat migrációjához viszonyítva.

Kontrollváltozóként a modellben a két település adottságaiban észlelhető különbségeket használjuk. Emellett a távolság szerepét a települések közti utazási idő és annak négyzetes tagja segítségével számszerűsítjük.

Elsőként ebben az esetben is az előző év vándorlásainak hatását becsüljük longitudinális adatok alapján:

$$
\frac{M_{i j t}}{M_{i t}}=\alpha+\boldsymbol{\beta}_{1}\left(\boldsymbol{f}_{\boldsymbol{j}, \boldsymbol{t}-\mathbf{1}}-\boldsymbol{f}_{\boldsymbol{i}, \boldsymbol{t}-\mathbf{1}}\right)+\beta_{2} k_{i j t}+\boldsymbol{\gamma} \boldsymbol{D}_{\boldsymbol{i}}+\boldsymbol{\delta} \boldsymbol{D}_{\boldsymbol{j}}+\varepsilon_{i j t}+\xi_{i j}
$$

ahol $M=$ migráció, „i” településről „j” településre a „t” évben. $f_{j, t-1}-f_{i, t-1}$ a települések adottságaira vonatkozó faktorok különbsége a megelőző évben. „k” a megelőző két évben a célhely viszonylatában történő vándorlás és a teljes elvándorlás aránya $\left(k_{i t}=\frac{M_{i j, t-1}+M_{i j, t-2}}{M_{j, t-1}+M_{j, t-2}}\right) . D_{i}$ és $D_{j}$ pedig a küldő és fogadó településre vonatkozó fix hatás (dummy) tag. $\varepsilon_{i j t}$ és $\xi_{i j}$ a hibatagok. A modellt két lépésben becsültük: ${ }^{2}$ elsőként csak a küldő település fix hatással, majd a teljes egyenletet mindkét fix hatással. A fix hatást a küldő településre beállítva az $\left(f_{j, t-1}-f_{i, t-1}\right)$ tag varianciáját a fogadó település adottságai fogják befolyásolni, a $\beta_{1}$ koefficiens becslései tehát azt fogják tükrözni, hogy az adott településről elvándorlók esetében hogyan érvényesülnek a fogadó település push és pull hatásai. A két fix hatás egy regresszióban abszorbálja az elvándorlók és letelepedők körében érvényesülő push és pull hatásokat is, azonban megjegyzendő, hogy továbbra is keresztmetszetből történik az identifikáció, ugyanis nem használunk a küldő és fogadó településpárra vonatkozó $D_{i j}$ fix hatást. Ennek megfelelően a modell azt vizsgálja, hogy egy adott településről többen vándorolnak-e olyan helyre, ahova korábban sokan mentek, figyelembe véve a települések adottságait, és nem azt, hogy adott településpár viszonylatában többen vándorolnak-e a következő évben, ha előző évben sokan tették.

Ezt követően a kapcsolatháló szerepét az iWiW-adatok révén vontuk be a modellbe, azonban - mivel az iWiW-adatokat a korábban leírtaknak megfelelően nem tartottuk alkalmasnak idősoros elemzésre - a modell ebben az esetben is csak egy évre (2014) vonatkozik:

$$
\frac{M_{i j}}{M_{i}}=\alpha+\boldsymbol{\beta}_{1}\left(\boldsymbol{f}_{\boldsymbol{j}}-\boldsymbol{f}_{\boldsymbol{i}}\right)+\beta_{2} k_{i}+\beta_{3} c_{i j}+\boldsymbol{\gamma} \boldsymbol{D}_{\boldsymbol{i}}+\boldsymbol{\delta} \boldsymbol{D}_{\boldsymbol{j}}+\varepsilon_{i j}+\xi_{i},
$$

ahol „c” az iWiW közösségi oldalon a két település közti kapcsolatok száma a küldő település összes külső, azaz településen kívüli kapcsolatához viszonyítva. A (2) egyenlethez hasonlóan a településjellemzőket leíró „f” faktorok és az iWiW kapcsolatokat leíró „c” változó egy évvel késleltetett a függő változóhoz képest (2013-ra vonatkozik).

2 A többdimenziós fix hatásokat tartalmazó modellek becsléséhez Stata programcsomag- „reghdfe” modulját használtuk, az egy dimenzióshoz "areg" parancsot. 


\begin{tabular}{|c|c|c|c|c|}
\hline & \begin{tabular}{|c|} 
Megfigye- \\
lések száma
\end{tabular} & Átlag & Medián & Szórás \\
\hline \multicolumn{5}{|l|}{ Településszint } \\
\hline Elvándorlási arány & 3154 & 0,0546 & 0,0475 & 0,0529 \\
\hline Elvándorlási arány (főváros) & 1 & 0,0703 & & \\
\hline Elvándorlási arány (megyeszékhelyek) & 18 & 0,0554 & & \\
\hline Elvándorlási arány (városok) & 287 & 0,0541 & & \\
\hline Elvándorlási arány (falvak) & 2844 & 0,0672 & & \\
\hline Iwiw-felhasználók száma településenként & 2576 & 1246 & 218,5 & 15724 \\
\hline Lakónépesség száma az év végén & 3154 & 3124 & 814 & 32517 \\
\hline Az egy iwiw-felhasználóra jutó külső kapcsolatok & 2576 & 173,6 & 169,41 & 39,29 \\
\hline Az egy iwiw-felhasználóra jutó belső kapcsolatok & 2576 & 52,28 & 45,63 & 32,81 \\
\hline \multicolumn{5}{|l|}{ Településpárok } \\
\hline $\begin{array}{l}\text { Az adott településre irányuló kapcsolatok aránya } \\
\text { az összes külső kapcsolathoz képest az iWiW-en }\end{array}$ & 470939 & 0,0054 & 0,0002 & 0,0318 \\
\hline
\end{tabular}

A főbb változók leíró statisztikái alapján (1. táblázat) látható, hogy az elvándorlási arányra vonatkozóan 3154 településre van megfigyelésünk a 2014-es évben (ami az ország összes települése), míg iWiW-felhasználót 2576 településen találunk a 2013as évben (ez a települések 81,67\%-a). Az elvándorlási arány átlaga településtípusonként azt mutatja, hogy a legnagyobb, 0,0703 elvándorlási arány Budapest esetében található, míg a magyarországi falvak átlagos elvándorlási aránya 0,0672. A városok és megyeszékhelyek elvándorlási aránya hasonló és alacsonyabb az előző kettőnél. Az iWiW-felhasználókra jutó külső és belső kapcsolatok adatai alapján azt látjuk, hogy nagyobb a más településen élőkkel fenntartott kapcsolatok súlya átlagosan a felhasználók körében. A második modell fő magyarázó változója - az adott településre irányuló kapcsolatok aránya az összes külső kapcsolathoz képest az iWiW-en - mediánja 0,0002, szórása pedig 0,0318.

\section{Eredmények}

\section{A települések elhagyása}

A települések elhagyására vonatkozó longitudinális elemzésben a korábbi évek elvándorlási aránya mindhárom specifikációban szignifikáns, és pozitív összefüggést mutat a következő év elvándorlási arányával. Ha a demográfiai csoportokra számított korábbi elvándorlást és a településre számított korábbi elvándorlást külön-külön modellben vizsgáljuk (2. táblázat 1-2. oszlop), akkor a demográfiai csoportokra számított változó esetében az együttható értéke 0,794, a teljes település elvándorlóira számított eltolt változó együtthatója pedig 1,276. Mindkét változót egyszerre az elemzésbe vonva továbbra is igaz, hogy hatásuk pozitív és szignifikáns, valamint az együtthatók nagysága is csak kismértékben változik, és a településszintú változó együtthatója a nagyobb. Ebből arra következtethetünk, hogy a kumulatív oksági 
hatás erősebben érvényesül a demográfiai csoportoktól függetlenül, és erősebbek a települések szintjén működő mechanizmusok. Összességében azonban mindhárom specifikáció alátámasztja a $\mathrm{H} 1 / \mathrm{b}$ hipotézisünket.

A települések adottságait mérő faktorok mint kontrollváltozók közül az első, második, negyedik és ötödik faktor nagyobb értékei egyértelműen pozitív adottságokat írnak le (több szolgáltatás és közszolgáltatás, erősebb helyi gazdaság). Ezek együtthatói a vártnak megfelelőn szinte kivétel nélkül szignifikánsak és negatívak, azaz a jobb ellátottság kevesebb elvándorlással társul.

2. táblázat: $A$ települések elhagyására vonatkozó longitudinális elemzés eredményei

\begin{tabular}{|c|c|c|c|}
\hline \multirow[b]{2}{*}{ Magyarázó változók } & (1) & (2) & (3) \\
\hline & \multicolumn{3}{|c|}{ Elvándorlási arány (demográfiai csoportonként) } \\
\hline \multirow[t]{2}{*}{$\begin{array}{l}\text { Elvándorlási arány, megelőző két év (teljes telepü- } \\
\text { lésre) }\end{array}$} & & $1,276 * * *$ & $1,443 * * *$ \\
\hline & & $(0,0232)$ & $(0,0372)$ \\
\hline \multirow[t]{2}{*}{$\begin{array}{l}\text { Elvándorlási arány, megelőző két év (demográfiai } \\
\text { csoportra) }\end{array}$} & $0.794 * * *$ & & $0.662 * * *$ \\
\hline & $(0.0114)$ & & $(0.0118)$ \\
\hline \multicolumn{4}{|l|}{ Település jellemzők (faktorok, megelőző egy év) } \\
\hline \multirow[t]{2}{*}{ Városi szolgáltatások } & $-0,000481 * * *$ & $-0,000445^{* * *}$ & $-0,000179 * * *$ \\
\hline & $(6.86 \mathrm{e}-05)$ & $(6.59 \mathrm{e}-05)$ & $(6.66 \mathrm{e}-05)$ \\
\hline \multirow[t]{2}{*}{ Helyi gazdaság } & $-0.000848^{* * *}$ & $0.000413 * * *$ & $-0.000572 * * *$ \\
\hline & $(0.000122)$ & $(0.000116)$ & $(0.000118)$ \\
\hline \multirow[t]{2}{*}{ Szolgáltató jelleg } & $-0.00131 * * *$ & $-0.00140 * * *$ & $-0.000947 * * *$ \\
\hline & $(0.000123)$ & $(0.000116)$ & $(0.000119)$ \\
\hline \multirow{2}{*}{ Alap közszolgáltatás } & $-0.000732 * * *$ & $-0.000866 * * *$ & $-0.000485 * * *$ \\
\hline & $(0.000101)$ & $(9.61 \mathrm{e}-05)$ & $(9.78 \mathrm{e}-05)$ \\
\hline \multirow[t]{2}{*}{ Munkaerőpiac } & $-0.000508 * * *$ & $-0.000749 * * *$ & $-5.10 e-05$ \\
\hline & $(0.000112)$ & $(0.000108)$ & $(0.000109)$ \\
\hline \multirow[t]{2}{*}{ Ipari jelleg } & $-0.00133 * * *$ & $-0.00114 * * *$ & $-0.000922 * * *$ \\
\hline & $(0.000132)$ & $(0.000123)$ & $(0.000128)$ \\
\hline \multicolumn{4}{|l|}{$\begin{array}{l}\text { Demográfiai csoportok (dummy, } 14 \text { éves kor feletti } \\
\text { népesség, viszonyítás: } 15-19 \text { éves nők) }\end{array}$} \\
\hline \multirow[t]{2}{*}{ 15-19 éves férfiak } & $-0.0203 * * *$ & $-0.0262 * \star *$ & $-0.0211 * * *$ \\
\hline & $(0.000467)$ & $(0.000454)$ & $(0.000467)$ \\
\hline \multirow[t]{2}{*}{ 20-29 éves nők } & $0.0249 * * *$ & $0.0317 * * *$ & $0.0260 * * *$ \\
\hline & $(0.000466)$ & $(0.000451)$ & $(0.000467)$ \\
\hline \multirow[t]{2}{*}{ 20-29 éves férfiak } & $-0.0101 * * *$ & $-0.0121 * * *$ & $-0.0104 * * *$ \\
\hline & $(0.000458)$ & $(0.000451)$ & $(0.000458)$ \\
\hline \multirow[t]{2}{*}{ 30-39 éves nők } & $-0.0101 * * *$ & $-0.0151 * * *$ & $-0.0107 * * *$ \\
\hline & $(0.000460)$ & $(0.000451)$ & $(0.000460)$ \\
\hline \multirow[t]{2}{*}{ 30-39 éves férfiak } & -0.0186 *** & $-0.0238 * * *$ & $-0.0194 * * *$ \\
\hline & $(0.000462)$ & $(0.000451)$ & $(0.000462)$ \\
\hline \multirow[t]{2}{*}{ 40-49 éves nők } & $-0.0411 * * *$ & $-0.0535^{* * *}$ & $-0.0429 * * *$ \\
\hline & $(0.000482)$ & $(0.000451)$ & $(0.000484)$ \\
\hline \multirow[t]{2}{*}{ 40-49 éves férfiak } & $-0.0418 * * *$ & $-0.0540 * * *$ & $-0.0436 * * *$ \\
\hline & $(0.000482)$ & $(0.000451)$ & $(0.000484)$ \\
\hline \multirow[t]{2}{*}{ 50-59 éves nők } & $-0.0511 * * *$ & $-0.0648^{* * *}$ & $-0.0532 * * *$ \\
\hline & $(0.000492)$ & $(0.000451)$ & $(0.000494)$ \\
\hline \multirow[t]{2}{*}{ 50-59 éves férfiak } & $-0.0512 * * *$ & $-0.0648 * * *$ & $-0.0533^{* * *}$ \\
\hline & $(0.000491)$ & $(0.000451)$ & $(0.000494)$ \\
\hline
\end{tabular}




\begin{tabular}{|c|c|c|c|}
\hline 60- éves nők & $-0.0499 * * *$ & $-0.0635 * * \star$ & $-0.0519 * * \star$ \\
\hline & $(0.000490)$ & $(0.000451)$ & $(0.000493)$ \\
\hline \multirow[t]{2}{*}{ 60- éves férfiak } & $-0.0526 * * *$ & $-0.0671 * * *$ & $-0.0548 * * *$ \\
\hline & $(0.000494)$ & $(0.000451)$ & $(0.000497)$ \\
\hline \multirow[t]{2}{*}{ Konstans } & $0.0709 * * *$ & $0.0708 * * *$ & $0.0548^{* * *}$ \\
\hline & $(0.000432)$ & $(0.000488)$ & $(0.000592)$ \\
\hline \multirow[t]{2}{*}{ var(_cons[telazev]) } & $0.000178 * * *$ & $0.000173 * * *$ & $0.000154 * * *$ \\
\hline & $(3.58 \mathrm{e}-06)$ & $(3.46 \mathrm{e}-06)$ & $(3.31 \mathrm{e}-06)$ \\
\hline \multirow[t]{2}{*}{ var(e.elvan_arany) } & $0.00186 * * *$ & $0.00208 * * *$ & $0.00186 * * *$ \\
\hline & $(5.91 \mathrm{e}-06)$ & $(6.17 \mathrm{e}-06)$ & $(5.90 \mathrm{e}-06)$ \\
\hline Megfigyelések & 216,287 & 247,634 & 216,287 \\
\hline Csoportok száma & 18,138 & 20,721 & 18,138 \\
\hline \multicolumn{4}{|c|}{ Standard hibák zárójelben } \\
\hline \multicolumn{4}{|c|}{$* * * \mathrm{p}<0,01 ; * * \mathrm{p}<0,05 ;{ }^{*} \mathrm{p}<0,1$} \\
\hline
\end{tabular}

A demográfiai csoportok dummy változóinak együtthatóit (3. oszlop) a könnyebb áttekinthetőség érdekében az 1. ábrán jelenítettük meg. A skálát +1-gyel eltolva látható az elvándorlók aránya a népességben demográfiai csoportonként. A bázis +1 , a 15-19 éves nők csoportja.

Mindkét nem esetében megfigyelhető, hogy a legmobilabbak a 20-29 évesek. A férfiak 30-39 éves korosztálya mobilabb, mint a 15-19 évesek; ez a nőknél fordítva van, a 15-19 éves korcsoport hajlamosabb az elvándorlásra, mint a 30-39 évesek. Majd mindkét nem esetében csökken a költözési kedv a későbbi életkorokban. Megfigyelhető továbbá, hogy majdnem minden korosztályban nagyobb a nők mobilitása a hasonló korú férfiakénál (1. ábra).

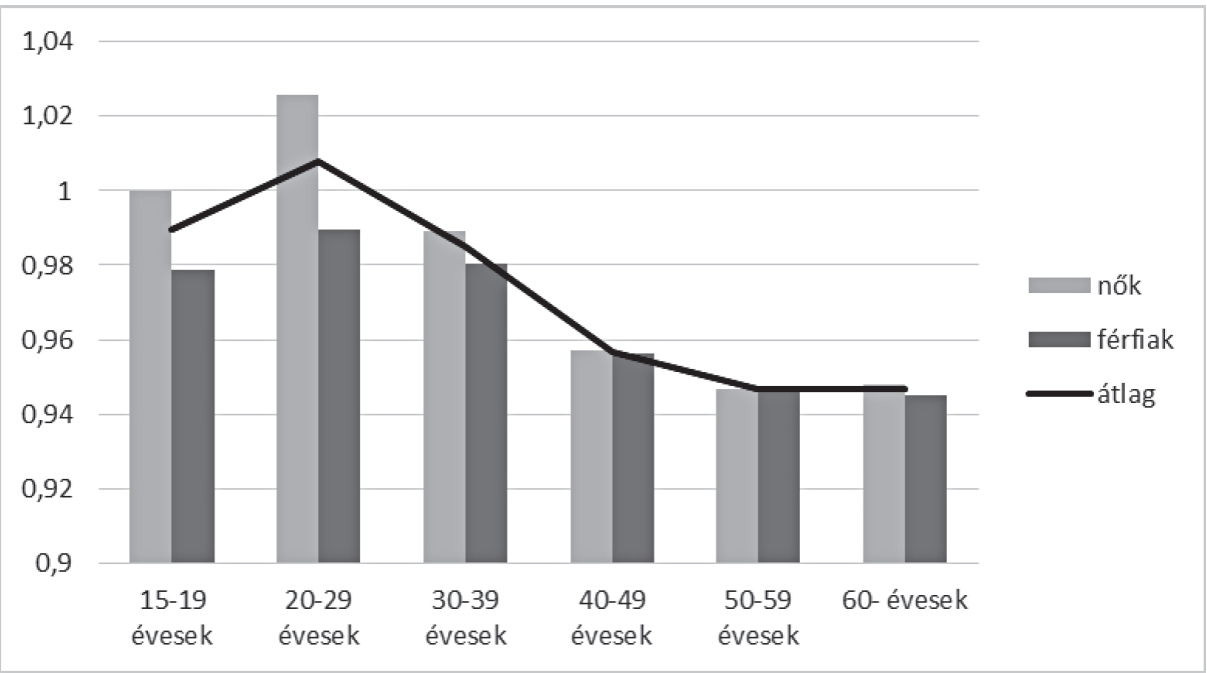


A közösségi hálón megfigyelhető kapcsolatok hatását vizsgáló modelleket a 3. táblázat tartalmazza. A táblázat 1. oszlopában a „külső kapcsolatok a közösségi hálón” változó hatása szignifikáns és pozitív, azaz több külső kapcsolat nagyobb elvándorlással társul, ami megfelel a H1/a hipotézisnek. A 2. oszlopban a megelőző évek vándorlását bevonva, tehát a H1/a és H1/b hipotézisekhez tartozó változókat egy modellben szerepeltetve azt látjuk, hogy mindkét hatás továbbra is szignifikáns és pozitív. A települések egy főre eső elvándorlóinak az elmúlt két év elvándorlóival való összefüggése itt is pozitív, tehát ha 2012-ben és 2013-ban a településről elvándorlók népességhez viszonyított aránya magas, akkor a 2014-ben elvándorlók népességhez viszonyított aránya is várhatóan magas. Az iWiW-en fenntartott, településen kívüli kapcsolatok aránya az összes kapcsolaton belül szintén szignifikáns összefüggést mutat az egy főre eső elvándorlókkal (0,0246) - minél nagyobb egy településen az adott évben a külső kapcsolatok aránya az összeshez képest, annál jellemzőbb az elvándorlás. Az előző évek vándorlását elemzésbe vonva az iWiW-változó együtthatója 0,0098-at veszít értékéből. Ez alapján nem valószínű, hogy a két változó tartalma megegyezne, vagy azonos látens mechanizmusok határoznák meg őket.

A demográfiai csoportok egymáshoz viszonyított elvándorlási hajlandóságának nagysága hasonló az előző modell alapján kapott eredményhez. A településjellemzőket leíró faktorok közül itt kevesebb szignifikáns hatást találunk - csak a harmadik és a hatodik faktor az (a nemzetgazdasági súlypontot jelölő faktorok).

\section{3. táblázat: A települések elhagyására vonatkozó keresztmetszeti elemzés eredményei}

\begin{tabular}{|c|c|c|}
\hline & (1) & (2) \\
\hline Magyarázó változók & \multicolumn{2}{|c|}{ Elvándorlási arány (demográfiai csoportonként) } \\
\hline \multirow[t]{2}{*}{$\begin{array}{l}\text { Elvándorlási arány, megelőző két év (demográfiai } \\
\text { csoportra) }\end{array}$} & & $1,136 * * *$ \\
\hline & & $(0,0393)$ \\
\hline \multirow{2}{*}{$\begin{array}{l}\text { iWiW-en fenntartott lakóhelyen belüli és kívüli } \\
\text { kapcsolatok aránya (demográfiai csoportonként) }\end{array}$} & $0.0344 * * *$ & $0.0246 * * *$ \\
\hline & $(0.00281)$ & $(0.00265)$ \\
\hline \multicolumn{3}{|l|}{ Településjellemzők (faktorok, megelőző egy év) } \\
\hline \multirow[t]{2}{*}{ Városi szolgáltatások } & 0.000250 & 0.000147 \\
\hline & $(0.000188)$ & $(0.000170)$ \\
\hline \multirow[t]{2}{*}{ Helyi gazdaság } & -0.000177 & $-9.36 e-05$ \\
\hline & $(0.000359)$ & $(0.000323)$ \\
\hline \multirow{2}{*}{ Szolgáltató jelleg } & $-0.00154 * * *$ & $-0.00136 * * *$ \\
\hline & $(0.000382)$ & $(0.000343)$ \\
\hline \multirow[t]{2}{*}{ Alap-közszolgáltatás } & -0.000403 & -0.000172 \\
\hline & $(0.000320)$ & $(0.000289)$ \\
\hline \multirow[t]{2}{*}{ Munkaerőpiac } & $-3.14 \mathrm{e}-05$ & 0.000170 \\
\hline & $(0.000371)$ & $(0.000333)$ \\
\hline \multirow[t]{2}{*}{ Ipari jelleg } & $-0.00243 * * *$ & $-0.00196 * * *$ \\
\hline & $(0.000495)$ & $(0.000444)$ \\
\hline \multicolumn{3}{|l|}{$\begin{array}{l}\text { Demográfiai csoportok (dummy, } 14 \text { éves kor } \\
\text { feletti népesség, viszonyítás: } 15-19 \text { éves nők) }\end{array}$} \\
\hline \multirow[t]{2}{*}{ 15-19 éves férfiak } & $-0.0295 * * *$ & $-0.0233 * * *$ \\
\hline & $(0.00129)$ & $(0.00128)$ \\
\hline \multirow[t]{2}{*}{ 20-29 éves nők } & $0.0212 * * *$ & $0.0144 * * *$ \\
\hline & $(0.00128)$ & $(0.00128)$ \\
\hline \multirow[t]{2}{*}{ 20-29 éves férfiak } & $-0.0247 * * *$ & $-0.0192 * * *$ \\
\hline & $(0.00127)$ & $(0.00125)$ \\
\hline \multirow[t]{2}{*}{ 30-39 éves nők } & $-0.0167 * * *$ & $-0.0127 * * *$ \\
\hline & $(0.00128)$ & $(0.00126)$ \\
\hline
\end{tabular}




\begin{tabular}{|c|c|c|}
\hline \multirow{2}{*}{ 30-39 éves férfiak } & $-0.0318 * * *$ & $-0.0236 * * *$ \\
\hline & $(0.00129)$ & $(0.00129)$ \\
\hline \multirow{2}{*}{ 40-49 éves nök } & $-0.0574 * * *$ & $-0.0426 * * *$ \\
\hline & $(0.00126)$ & $(0.00133)$ \\
\hline \multirow{2}{*}{ 40-49 éves férfiak } & $-0.0620 * * *$ & $-0.0464 * * *$ \\
\hline & $(0.00128)$ & $(0.00136)$ \\
\hline \multirow[t]{2}{*}{ 50-59 éves nök } & $-0.0744 * * *$ & $-0.0557 * * *$ \\
\hline & $(0.00125)$ & $(0.00138)$ \\
\hline \multirow{2}{*}{ 50-59 éves férfiak } & $-0.0760 * * *$ & $-0.0569 * * *$ \\
\hline & $(0.00127)$ & $(0.00140)$ \\
\hline \multirow[t]{2}{*}{ 60- éves nök } & $-0.0723 * * *$ & $-0.0541 * * *$ \\
\hline & $(0.00127)$ & $(0.00138)$ \\
\hline \multirow[t]{2}{*}{ 60-éves férfiak } & $-0.0780 * * *$ & $-0.0585 * * *$ \\
\hline & $(0.00130)$ & $(0.00143)$ \\
\hline \multirow[t]{2}{*}{ Konstans } & $0.0771 * * *$ & $0.0580 * * *$ \\
\hline & $(0.00200)$ & $(0.00199)$ \\
\hline \multirow[t]{2}{*}{ var(_cons[telazev]) } & $0.000119 * * *$ & $7.88 \mathrm{e}-05^{* * *}$ \\
\hline & $(7.85 \mathrm{e}-06)$ & $(6.45 \mathrm{e}-06)$ \\
\hline \multirow{2}{*}{ var(e.elvan_arany) } & $0.00123 * * *$ & $0.00118 * * *$ \\
\hline & $(1.27 e-05)$ & $(1.22 \mathrm{e}-05)$ \\
\hline \multirow{2}{*}{$\begin{array}{l}\text { Megfigyelések } \\
\text { Csoportok száma }\end{array}$} & 20.684 & 20.651 \\
\hline & 1,800 & 1,800 \\
\hline \multirow{2}{*}{ Csoportok száma } & rójelben & \\
\hline & $5 ; * p<0,1$ & \\
\hline
\end{tabular}

Robusztusságvizsgálatot végeztünk mind az első, mind a második modellünkre egy szűrt mintán, amely csak azokat a településeket tartalmazza, ahol legalább 100 iWiW-felhasználót megfigyeltünk. Amint a percentilis értékekból (4. táblázat) látható, ezzel kb. az esetek egynegyedét zártuk ki. Az eredmények az eredetiekhez képest csak minimális eltérést mutatnak a vizsgált magyarázó változók tekintetében.

4. táblázat: Az iWiW-felhasználók száma településenként, percentilisek

\begin{tabular}{|c|c|}
\hline Percentilis & Határérték \\
\hline $1 \%$ & 17 \\
\hline $5 \%$ & 38 \\
\hline $10 \%$ & 55 \\
\hline $25 \%$ & 102 \\
\hline $50 \%$ & 218,5 \\
\hline $75 \%$ & 512 \\
\hline $90 \%$ & 1451 \\
\hline $95 \%$ & 3370 \\
\hline $99 \%$ & 12878
\end{tabular}

\section{A letelepedés helyének kiválasztása}

A letelepedés helyének kiválasztására vonatkozó longitudinális elemzésben a két település közötti korábbi migráció hatását (H2/b hipotézis) két specifikációban vizsgáljuk. Mindkét regresszióban megegyeznek a függő és magyarázó változók, ezek mindössze annyiban különböznek, hogy fix hatás dummykat a küldő, vagy mindkét település vonatkozásában tartalmaznak (5. táblázat). A két fix hatás abszorbálja az elvándorlók és a letelepedők körében hatást gyakorló push és pull hatásokat, míg az 1-es oszlopban a küldő településre beállítva azt látjuk, hogy az adott településről elvándorlók esetében hogyan érvényesülnek a fogadó települések push és pull hatásai. 
Mindkét specifikáció esetében igaz, hogy azon településpárok esetében lesz magas a költözési arány, amely viszonylatban a megelőző két évben is sokan költöztek, a H2/b hipotézisünknek megfelelően.

A településjellemzőket leíró faktorok esetében a fogadó és a küldő település különbségei szerepelnek a modellben magyarázó változóként. Ahol a faktorértékek jobb ellátottságot jelentenek (1., 2., 4., 5. faktor), ott a pozitív együttható felel meg a várakozásunknak (a relatíve jobb helyzetben lévő településre többen költöznek feltételezhetően). Látható, hogy ez a négy faktor esetéből háromban teljesül.

A települések időben mért távolságának és a viszonylat népszerűségének (az adott településről az összes elvándorló és az adott célhelyet választók aránya) fordított a kapcsolata. Minél távolabb van egy település a származási helyhez képest, annál kevésbé választják azt a vándorlók, a várakozásoknak megfelelően. A négyzetes tagból kiderül, hogy tulajdonképpen csökkenő ütemben csökken a távoli települések kiválasztása.

5. táblázat: A letelepedés helyének kiválasztására vonatkozó longitudinális elemzés eredményei

\begin{tabular}{|c|c|c|}
\hline \multirow{3}{*}{$\begin{array}{l}\text { Magyarázó változók } \\
\text { Megelőző } 2 \text { évben adott célhelyet választók aránya (adott } \\
\text { településről összes elvándorlóhoz viszonyítva) }\end{array}$} & \multirow{2}{*}{\multicolumn{2}{|c|}{\begin{tabular}{c|c} 
(1) & $(2)$ \\
Adott célhelyet választók \\
aránya (adott településröl összes \\
elvándorlóhoz viszonyítva)
\end{tabular}}} \\
\hline & & \\
\hline & $0,590 * * *$ & $0,395 * * *$ \\
\hline & $(0,00232)$ & $(0,000516)$ \\
\hline \multirow[t]{2}{*}{ Útidő (perc) } & $-1.41 \mathrm{e}-05^{* * *}$ & $-1.89 \mathrm{e}-05^{* * *}$ \\
\hline & $(1.05 \mathrm{e}-07)$ & $(9.13 e-08)$ \\
\hline \multirow[t]{2}{*}{ Útidő négyzete } & $6.94 \mathrm{e}-10 * * *$ & $9.46 \mathrm{e}-10 * * *$ \\
\hline & $(9.14 \mathrm{e}-11)$ & $(2.81 \mathrm{e}-11)$ \\
\hline \multicolumn{3}{|l|}{$\begin{array}{l}\text { Településjellemzők (fogadó-küldő település faktor különbségei, } \\
\text { megelőző egy év) }\end{array}$} \\
\hline \multirow[t]{2}{*}{ Városi szolgáltatások } & $0.000535 * * *$ & $2.79 \mathrm{e}-05^{* * *}$ \\
\hline & $(3.37 e-06)$ & $(1.08 \mathrm{e}-05)$ \\
\hline \multirow[t]{2}{*}{ Helyi gazdaság } & $-0.000643 * * *$ & $9.71 \mathrm{e}-05^{* * *}$ \\
\hline & $(8.96 \mathrm{e}-06)$ & $(1.28 \mathrm{e}-05)$ \\
\hline \multirow[t]{2}{*}{ Szolgáltató jelleg } & $-0.000143 * * *$ & $4.38 \mathrm{e}-06$ \\
\hline & $(6.86 e-06)$ & $(1.33 e-05)$ \\
\hline \multirow[t]{2}{*}{ Alap-közszolgáltatás } & $0.000242 * * *$ & $2.66 \mathrm{e}-05$ \\
\hline & $(8.22 \mathrm{e}-06)$ & $(1.65 e-05)$ \\
\hline \multirow[t]{2}{*}{ Munkaerőpiac } & $0.000515^{\star * \star}$ & $6.00 \mathrm{e}-05^{* * *}$ \\
\hline & $(7.45 \mathrm{e}-06)$ & $(1.36 \mathrm{e}-05)$ \\
\hline \multirow[t]{2}{*}{ Ipari jelleg } & $-0.000181 * * *$ & $-1.11 e-05$ \\
\hline & $(7.91 \mathrm{e}-06)$ & $(9.88 \mathrm{e}-06)$ \\
\hline Küldő település fix hatás & igen & igen \\
\hline Fogadó település fix hatás & nem & igen \\
\hline \multirow[t]{2}{*}{ Konstans } & $0.00375 * * *$ & \\
\hline & $(2.05 e-05)$ & \\
\hline Megfigyelések & $5,295,633$ & $5,295,633$ \\
\hline R négyzet & 0.348 & 0.399 \\
\hline \multicolumn{3}{|l|}{ Standard hibák zárójelben } \\
\hline$* * * p<0,01 ;{ }^{* *} p<0,05 ; * p<0,1$ & & \\
\hline
\end{tabular}


A letelepedés helyének vizsgálatára vonatkozó keresztmetszeti elemzésben három specifikációt vizsgálunk. Elsőként az iWiW-kapcsolatok változóját vonjuk be a modellbe, fix hatással a küldő településekre (6. táblázat 1. oszlop). Ezután az elmúlt két év migrációját is bevonjuk, hogy a H2/a és H2/b hipotéziseket egy modellben vizsgálhassuk. Ezen belül elsőként a küldő településre, ezután egyszerre a küldő és fogadó településre is vonunk be fix hatást (6. táblázat 2-3. oszlop).

Az iWiW-kapcsolatok együtthatója minden specifikációban pozitív és szignifikáns, azaz a közösségi hálón a célhellyel (a többi alternatívához képesti) sűrűbb kapcsolatháló népszerúbbé teszi az adott viszonylatot, ami megfelel a H2/a hipotézisnek.

A megelőző két év vándorlása itt is hasonlóképpen fest, mint a longitudinális elemzésnél. Jellemző, hogy olyan viszonylatokban gyakoribb a költözés, amelyek a korábbi években is népszerúek voltak. Látható az is, hogy a korábbi évek vándorlását bevonva az iWiW-kapcsolatok együtthatója körülbelül felére csökken. Ez nem meglepő, tekintve, hogy a költözés után az emberek megtartják kapcsolataikat (illetve azok egy részét), ami miatt a települések közötti kapcsolatok és a korábbi költözések pozitív összefüggést mutatnak.

A településjellemzőket leíró faktorok hatása nagyrészt megegyezik a longitudinális elemzés során tapasztalttal. Az emberek olyan irányba költöznek, ahol jobbak a városi szolgáltatások, az alapvető közszolgáltatások és a munkaerőpiaci helyzet, míg a második, helyi gazdaság faktor előjele a várakozásokkal szemben negatív.

$\mathrm{Az}$ ipari és mezőgazdasági jelleg, valamint a munkaerőpiaci jellemzőket leíró faktorok estében az azonos településről érkezők (küldő település fix hatás) nem választanak szolgáltatói és ipari jellegűbb, valamint kevésbé mezőgazdasági nemzetgazdasági súlyú településeket. A munkaerőpiac tekintetében az azonos településről érkezők (küldő település fix hatás) a kedvezőbb helyzetű településeket választják (több ivóvízhálózatba kapcsolt lakás és kevesebb tartós álláskereső).

A két fix hatásos modellben (5. oszlop) a településjellemzők keresztmetszeti különbségét jellemzően felveszi a két fix hatás, így a faktorok változóinak együtthatói inszignifikánssá válnak. 
6. táblázat: A letelepedés helyének kiválasztására vonatkozó keresztmetszeti elemzés eredményei

\begin{tabular}{|c|c|c|c|}
\hline \multirow[b]{2}{*}{ Magyarázó változók } & (1) & $(2)$ & (3) \\
\hline & \multicolumn{3}{|c|}{$\begin{array}{c}\text { Adott célhelyet választók aránya (adott } \\
\text { településről az összes elvándorlóhoz viszonyítva) }\end{array}$} \\
\hline \multirow[t]{2}{*}{$\begin{array}{l}\text { Megelőző } 2 \text { évben adott célhelyet választók } \\
\text { aránya (adott településről összes elvándorlóhoz } \\
\text { viszonyítva) }\end{array}$} & & $0,319 * * *$ & $0,319 * * *$ \\
\hline & & $(0,00886)$ & $(0,00886)$ \\
\hline \multirow[t]{2}{*}{$\begin{array}{l}\text { Adott településre irányuló kapcsolatok aránya az } \\
\text { összes külső kapcsolathoz képest az iWiW-en }\end{array}$} & $0.112 * * *$ & $0.0733 * * *$ & $0.0732 * * *$ \\
\hline & $(0.00238)$ & $(0.00178)$ & $(0.00178)$ \\
\hline \multirow[t]{2}{*}{ Útidő (perc) } & $-1.77 e-05^{* * *}$ & $-1.20 \mathrm{e}-05^{* * *}$ & $-1.18 \mathrm{e}-05^{* * *}$ \\
\hline & $(2.91 \mathrm{e}-07)$ & $(3.24 \mathrm{e}-07)$ & $(3.31 \mathrm{e}-07)$ \\
\hline \multirow[t]{2}{*}{ Útidő négyzete } & $7.67 e-10 * * *$ & $5.19 \mathrm{e}-10 * * *$ & $5.11 \mathrm{e}-10 * * *$ \\
\hline & (0) & (0) & (0) \\
\hline \multirow[t]{2}{*}{ Fogadó település népessége } & $7.73 \mathrm{e}-09 * * *$ & $4.24 \mathrm{e}-09 * *$ & \\
\hline & $(2.01 \mathrm{e}-09)$ & $(1.90 \mathrm{e}-09)$ & \\
\hline \multicolumn{4}{|l|}{ Fogadó település típusa (referenciakategória: falu) } \\
\hline \multirow[t]{2}{*}{ Főváros } & $0.105 * * *$ & $0.0723 * * *$ & \\
\hline & $(0.00380)$ & $(0.00360)$ & \\
\hline \multirow[t]{2}{*}{ Megyeszékhely } & $0.000462 * *$ & 0.000265 & \\
\hline & $(0.000194)$ & $(0.000188)$ & \\
\hline \multirow[t]{2}{*}{ Város } & $0.000129 * *$ & $4.31 \mathrm{e}-05$ & \\
\hline & $(5.56 \mathrm{e}-05)$ & $(5.58 \mathrm{e}-05)$ & \\
\hline \multicolumn{4}{|l|}{$\begin{array}{l}\text { Településjellemzők (fogadó-küldő település faktor } \\
\text { különbségei, megelőző egy év) }\end{array}$} \\
\hline \multirow[t]{2}{*}{ Városi szolgáltatások } & $0.000138 * * *$ & $0.000104^{* * *}$ & $8.15 \mathrm{e}-05 * * *$ \\
\hline & $(1.28 \mathrm{e}-05)$ & $(1.26 \mathrm{e}-05)$ & $(1.22 \mathrm{e}-05)$ \\
\hline \multirow[t]{2}{*}{ Helyi gazdaság } & $-7.63 e-05^{* * *}$ & $-5.63 e-05^{* * *}$ & $-4.24 e-05^{* *}$ \\
\hline & $(1.89 \mathrm{e}-05)$ & $(1.89 \mathrm{e}-05)$ & $(1.93 e-05)$ \\
\hline \multirow[t]{2}{*}{ Szolgáltató jelleg } & $-9.27 e-05^{* * *}$ & $-5.98 \mathrm{e}-05^{* * *}$ & $-4.02 e-05^{*}$ \\
\hline & $(1.99 \mathrm{e}-05)$ & $(1.99 \mathrm{e}-05)$ & $(2.29 \mathrm{e}-05)$ \\
\hline \multirow[t]{2}{*}{ Alap-közszolgáltatás } & $5.18 \mathrm{e}-05^{* *}$ & $4.05 e-05^{*}$ & $4.59 \mathrm{e}-05^{*}$ \\
\hline & $(2.39 \mathrm{e}-05)$ & $(2.38 \mathrm{e}-05)$ & $(2.36 \mathrm{e}-05)$ \\
\hline \multirow[t]{2}{*}{ Munkaerőpiac } & $-6.11 e-05^{* * *}$ & $-3.51 e-05^{*}$ & $-6.96 \mathrm{e}-05^{* * *}$ \\
\hline & $(1.85 e-05)$ & $(1.85 \mathrm{e}-05)$ & $(2.18 \mathrm{e}-05)$ \\
\hline \multirow[t]{2}{*}{ Ipari jelleg } & $-1.30 e-06$ & $-9.42 e-06$ & $1.16 \mathrm{e}-05$ \\
\hline & $(2.72 \mathrm{e}-05)$ & $(2.74 \mathrm{e}-05)$ & $(2.98 \mathrm{e}-05)$ \\
\hline Küldő település fix hatás & igen & igen & igen \\
\hline Fogadó település fix hatás & nem & nem & igen \\
\hline \multirow[t]{2}{*}{ Konstans } & $0.00519 * * *$ & $0.00357 * * *$ & \\
\hline & $(5.52 \mathrm{e}-05)$ & $(7.06 e-05)$ & \\
\hline \multirow{2}{*}{$\begin{array}{l}\text { Megfigyelések } \\
R \text { négyzet }\end{array}$} & 332,526 & 332,526 & 332,526 \\
\hline & 0.508 & 0.541 & 0.541 \\
\hline \multicolumn{4}{|c|}{ Standard hibák zárójelben } \\
\hline 0,01 & $<0,05 ;{ }^{*} p<0,1$ & & \\
\hline
\end{tabular}

\section{Következtetések}

Kutatásunk a kapcsolathálók magyarországi belföldi vándorlásban játszott szerepével foglalkozik. Külön vizsgáltuk a települések elhagyását és a letelepedés helyének kiválasztását befolyásoló hatásokat - azaz az elvándorlást és a célhely kiválasztását. Longitudinális adataink a 2000-2014 közötti időszakra, a keresztmetszeti modellek 2014-re vonatkoznak. 
A származási települések és a célhely-alternatívák infrastrukturális és gazdasági jellemzői mellett a kapcsolathálózati lehetőségek további push és pull faktorokként jelennek meg. A méréskor megkülönböztettük ezért a települések jellemzőit településstatisztikai adatbázis alapján és a települések közti távolságot útidőben. A települések elhagyásának arányát teljes településre és demográfiai csoportokra, az egyes viszonylatok népszerűségét pedig a többi alternatívához képest értelmeztük. A kapcsolathálók hatását a közösségi hálón fenntartott kapcsolatokkal, a kumulatív oksági hatást pedig az elmúlt évek vándorlásával mértük.

Az eredmények azt mutatják, hogy mind az elvándorlással, mind a letelepedéssel szignifikáns és pozitív összefüggésben vannak a hálózati hatások. Mind a kumulatív okság, mind a kapcsolathálók hatással vannak az aktuális évi vándorlás irányára és mértékére. Az életkor elvándorlással való összefüggése megfelel a várakozásnak (Schultz 1983; Oldakowski-Roseman 1986; (Clark-Hunter 1992); Greenwood 1997), a 20-29 éves korosztály a legmobilabb mindkét nem esetében, majd az életkor elörehaladtával csökken a vándorlás. Eredményeink azt mutatják, hogy a nők minden korcsoportban többet vándorolnak belföldön, mint a férfiak, ami megfelel a korábbi magyar kutatásoknak (Gödri-Spéder 2009). E tekintetben eltérnek a belföldi és a nemzetközi vándorlás nemek szerinti jellegzetességei. A települések közti távolság növekedésével csökken az adott település népszerűsége a többi lehetséges célponthoz képest.

A településjellemzők a települések elhagyására vonatkozóan a vártnak megfelelő hatást mutatnak, a jobb adottságokkal (városi szolgáltatások, helyi gazdaság, alapközszolgáltatás, munkaerőpiac) rendelkező településeket kevesebben hagyják el. A szolgáltató és ipari jelleget mérő faktorok alapján jellemzőbb az elvándorlás a mezőgazdasági és ipari nemzetgazdasági súlyú településekről, és kevésbé a szolgáltatás nemzetgazdasági ágak jelenléte esetében. A letelepedés helyének kiválasztásakor a jobb adottságokkal (városi szolgáltatások, helyi gazdaság, alap-közszolgáltatás, munkaerőpiac) bíró településeket nagyobb arányban választják. A helyi gazdaságot leíró faktor a várttal ellentétesen hat, kevésbé vonzza a letelepülőket.

A közösségi hálón fenntartott kapcsolatok és a korábbi évek migrációjának az adott évi migrációval való összefüggését mindkét kontextusban sikerült megállapítani. Egyrészt a kiterjedt külső kapcsolathálóval rendelkező településekről nagyobb arányban vándorolnak el, kontrollálva a településjellemzőkre és demográfiai csoportok különböző endogén jellemzőire. Összhangban Haug (2008) eredményeivel, minél nagyobb egy településen a külső kapcsolatok aránya az összes kapcsolaton belül, annál jellemzőbb az elvándorlás.

Másrészt ez érvényesül a településpárok viszonylatában is: két település közt, ha a többi alternatívához képest több az iWiW-felhasználók közt a kapcsolat, akkor az népszerűbb célhellyé teszi a települést a többi lehetőséghez képest. A célhelyalternatívák pull faktorai között tehát a potenciális kapcsolatháló értéke jelentős, ahogy azt Nowotny és Pennerstorfer (2012) megállapították. A kapcsolathálózatok 
jelentősége az, hogy csökkentik az információk megszerzésének költségeit és segítik a beilleszkedést, csökkentik a pszichés terheket (DaVanzo 1981; Deléchat 2001; Beaman 2012).

Feltételezhető, hogy a kapcsolatok földrajzi eloszlása összefügg a földrajzi térben való vándorlással, és nem csak az egyén vándorlása van hatással a saját, földrajzi térben definiált kapcsolathálójára, hanem a kapcsolatainak a vándorlása is. Az tehát, hogy egy adott településen a lakók kiterjedt kapcsolatokkal rendelkeznek más településekkel, következhet abból, hogy korábban sokan vándoroltak el onnan, és az ottmaradók fenntartják a kapcsolatokat az elvándoroltakkal. Így fontos szempont, hogy az elmúlt évek vándorlása hogyan függ össze az aktuális évi vándorlással.

Eredményeink azt mutatják, hogy a migráció származási közösségben való korábbi intenzitása szignifikáns kapcsolatban van az elvándorlással a 2000-2014-ig tartó időszakban és a 2014-es évre vonatkozóan is, ami összefüggésbe hozható a kumulatív oksági hatással (Massey et al. 1993, 1994). Ez a hatás az elvándorlók kiválasztódásában is érvényesül - közösségi szinten gyakoribb a migráció ott, ahol a közösségből már sokan elvándoroltak vagy rendelkeznek migrációs tapasztalattal (Deléchat 2001). A településpárok esetében is, amelyik viszonylat népszerű volt a megelőző években, az népszerű lesz az adott évben is.

A megelőző évek vándorlását az adott településen az adott demográfiai csoportban mért korábbi migrációra és a település lakóinak átlagos korábbi migrációjára különválasztva azt találjuk, hogy ez a mechanizmus inkább települések szintjén, mint a településen belüli demográfiai csoportok szintjén hat.

A közösségi oldal segítségével mért kapcsolatháló és a korábbi évek vándorlásának egy modellbe történő bevonásával azt tapasztaltuk, hogy ezek hatásában átfedés tapasztalható: a kapcsolatháló változó hatása gyengül, de továbbra is mindkét hatás szignifikáns. A települések közti vándorlás és az egyéni kapcsolathálók térbeli elrendeződése tehát össze is függ, másrészt egy irányba ható, párhuzamosan müködő migrációt gerjesztő jelenségekről van szó. Ez az eredmény megegyezik Bauer, Epstein és Gang (2002) mexikói bevándorlók amerikai letelepedési helyét vizsgáló eredményeivel.

Tanulmányunkban az iWiW közösségi hálón fenntartott kapcsolatokat a „valós” kapcsolathálót leíró proxy változóként kezeltük, azonban ki kell térnünk az ezzel kapcsolatos limitációkra is. Az elemzésbe bevont kapcsolatháló az iWiW 2013-as állapotát tükrözi, melyre azért esett a választás, hogy a lehető legkisebb mértékben érvényesüljön a szelekciós hatás (például amiatt, hogy a kistelepülésen élők jellemzően később regisztráltak az iWiW-re, mint a nagyvárosiak). Ezzel együtt is igaz azonban, hogy a közösségi hálón „csak” 3,77 millió felhasználó van jelen, ami az akkori internethasználó népesség kb. kétharmadának felel meg, azonban a fennmaradó egyharmad és a nem internethasználó népesség értelemszerúen nem szerepel az adatbázisban. Emiatt felmerül viszont, hogy a regisztrált felhasználók nem biztos, hogy aktívak már ebben az időszakban, valamint a profilok tulajdonosai különböző célból és különböző időkö- 
zönként látogatják a közösségi hálót. Emiatt számolni kell az információk elavulásával: nem biztos, hogy az inaktív felhasználók lakhelye időközben nem változott meg, de az sem biztos, hogy az aktív felhasználók megfelelően karbantartják az adataikat, beírják például a lakhelyüket vagy családi állapotukat, amikor az megváltozik. Abban az esetben, ha egy felhasználó elköltözik, de ezt nem tudjuk megfigyelni, mert nem változtatja meg az adatait az iWiW-en, és ezután új kapcsolatokra tesz szert új lakóhelyén, ami megjelenik az iWiW-adatbázisban, akkor a két település között a valósnál több kapcsolatot figyelünk meg, így a modellben a kapcsolathálónak tulajdoníthatunk olyan hatást, ami igazából a kumulatív okságnak köszönhető.

\begin{abstract}
Our research focuses on the role of social networks in Hungarian migration. Previous studies have shown the impact of networks on migration in the context of international migration, in this study we analyze this pattern considering internal migration. We examine separately the factors determining the out-migration from settlements and the factors determining the location choice of internal migrants. The network effects appear in our model as push and pull factors in addition to the infrastructural and economic characteristics of the source settlements and destination alternatives. The characteristics of the settlements are included in the analysis based on official data, and the distance between settlements are indicated by the travel time. The effect of social networks has been measured by the migration rate of previous years and by the intensity of user-user connections on iWiW social network site between two cities. We analyze longitudinal data for the 2000-2014 period, and the cross-sectional models are for the year 2014. We used multilevel and fixed-effect regression models for the analysis. Our results show that both leaving and choosing settlements are associated with the network effects: the migration of previous years and the connections on iWiW also have an impact on the current migration rate.
\end{abstract}

Keywords: internal migration, social network, cumulative causation, network effect, place utility, online social networks

\title{
Irodalom
}

Bálint L. - Gödri I. (2015): Belföldi vándorlás. In Monostori J. - Őri P. - Spéder Zs. (szerk.): Demográfiai portré. Budapest: KSH NKI, 171-186. http:// demografia.hu/kiadvanyokonline/index.php/demografiaiportre/article/ download/2485/2483.

Bauer, T. K. - Epstein, G. S. - Gang, I. N. (2002): Herd Effects or Migration Networks? The Location Choice of Mexican Immigrants in the U.S. IZA Discussion paper series, No. 551. https://www.iza.org/publications/dp/551/ herd-effects-or-migration-networks-the-location-choice-of-mexicanimmigrants-in-the-us.

Beaman, A. L. (2012): Social networks and the dynamics of labour market outcomes: Evidence from refugees resettled in the U.S. The Review of Economic Studies, 79(1), 128-161. https://doi.org/10.1093/restud/rdr017.

Blaskó Zs. - Gödri I. (2014): Kivándorlás Magyarországról: Szelekció és célország-választás az új migránsok körében. Demográfia, 57(4): 271-307. 
http://demografia.hu/kiadvanyokonline/index.php/demografia/article/ download/2636/2488.

Boyd, M. (1989): Family and personal networks in international migration: Recent developments and new agendas. The International Migration Review, 23(3), 638670. https://www.jstor.org/stable/2546433.

Brooks, B. - Hogan, B. - Ellison, N. - Lampe, C. - Vitak, J. (2014): Assessing structural correlates to social capital in Facebook ego networks. Social Networks, 38(1), 1-15. http://dx.doi.org/10.1016/j.socnet.2014.01.002.

Brown, A. L. - Longbrake, D. B. (1970): Migration flows in intraurban space: Place utility considerations. Annals of the Association of American Geographers, 60(2), 368-384. https://doi.org/10.1111/j.1467-8306.1970.tb00726.x.

Brown, D. L. - Schafft, K. A. (2002): Population deconcentration in Hungary during the post-socialist transformation. Journal of Rural Studies, 18(1), 233-244. https://doi.org/10.1016/S0743-0167(01)00046-8.

Clark, D. A. - Hunter W. J. (1992): The impact of economic opportunity, amenities and fiscal factors on age-specific migration rates. Journal of Regional Science, 32(3), 349-365. https://doi.org/10.1111/j.1467-9787.1992.tb00191.x.

DaVanzo, J. (1981): Repeat migration, information costs, and location-specific capital. Journal of Population and Environment, 4(1), 45-73. https://doi. org/10.1007/BF01362575.

Deléchat, C. (2001): International migration dynamics: The role of experience and social networks. Labour, 15(3), 457-486. https://doi.org/10.1111/14679914.00173.

Dorigo, G. - Tobler, W. (1983): Push-pull migration laws. Annals of the Association of American Geographers, 73(1), 1-11. https://doi.org/10.1111/j.1467-8306.1983. tb01392.x.

Dövényi Z. (2009): Belső vándormozgalom Magyarországon: folyamatok és struktúrák. Statisztikai Szemle, 87(7-8), 748-762. http://www.ksh.hu/statszemle_ archive/2009/2009_07-08/2009_07-08_748.pdf

Ellison, N. B. - Steinfield, C. - Lampe, C. (2007): The Benefits of Facebook "Friends:" Social capital and college students' use of online social network sites. Journal of Computer-Mediated Communication, 14(4), 1143-1168. https://doi. org/10.1111/j.1083-6101.2007.00367.x.

Gödri I. - Spéder Zs. (2009): Belföldi vándorlás. In Monostori J. - Őri P. Spéder Zs. (szerk.): Demográfiai portré. Budapest: KSH NKI, 109-117. http:// demografia.hu/kiadvanyokonline/index.php/demografiaiportre/article/ download/2485/2483.

Greenwood, M. J. (1997): Internal migration in developed countries. In Rosenzweig, M. R. - Stark, O. (eds.): Handbook of Population and Family Economics. Volume 1B. Amsterdam: Elsevier, 647-720. https://ideas.repec. org/h/eee/popchp/1-12.html. 
Gyáni G. (2003): A vándorlás mint kulturális jelenség. Demográfia, 46(4), 375-382. http://www.demografia.hu/kiadvanyokonline/index.php/demografia/ article/view/643/408.

Hagen-Zanker, J. (2008): Why do people migrate? A review of the theoretical literature. Maastricht Graduate School of Governance Working Paper. https:// mpra.ub.uni-muenchen.de/28197/1/MPRA_paper_28197.pdf.

Hampton, K. - Wellman, B. (2001): Long distance community in the network society: Contact and support beyond Netville. American Behavioral Scientist, 45(3), 476-495. https://doi.org/10.1177/00027640121957303.

Harris, J. R. - Todaro, M. P. (1970): Migration, unemployment and development: A two-sector analysis. The American Economic Review, 60(1), 126-142. https:// www.jstor.org/stable/1807860.

Haug, S. (2008): Migration networks and migration decision-making. Journal of Ethnic and Migration Studies, 34(4), 585-605. https://doi. org/10.1080/13691830801961605.

Hautzinger Z. - Hegedűs J. - Klenner Z. (2014): A migráció elmélete. Budapest: NKE. http://real.mtak.hu/16634/1/w207.bat_session\%3D1164013711\%26infile \%3D\%26sobj\%3D8961\%26cgimime\%3Dapplication\%252Fpdf.

Lengyel, B. - Di Clemente, R. - Kertész, J. - González, M. C. (2018): Spatial diffusion and churn of social media. arXiv:1804.01349. https://www. researchgate.net/profile/Balazs_Lengyel/publication/324218500_ The_role_of_geography_in_the_complex_diffusion_of_innovations/ links/5ac5ff0eaca2720544d045a6/The-role-of-geography-in-the-complexdiffusion-of-innovations.pdf.

Massey, D. S. - Goldring, L. - Durand, J. (1994): Continuities in transnational migration: An analysis of nineteen Mexican communities. American Journal of Sociology, 99(6), 1492-1533. https://doi.org/10.1086/230452.

Massey, D. S. - Arango, J. - Hugo, G. - Kouaouci, A. - Pellegrino, A. - Taylor, J. E. (1993): Theories of international migration: A review and appraisal. Population and development review, 19(3), 431-466. http://www.jstor.org/ stable/2938462.

Munshi, Kaivan (2003): Networks in the Modern Economy: Mexican Migrants in the US Labor Market. The Quarterly Journal of Economics, 118(2), 549-599. https://doi.org/10.1162/003355303321675455

Nowotny, K. - Pennerstorfer, D. (2012): Ethnic networks and the location choice of migrants in Europe. Working Papers in Economics and Finance - University of Salzburg - No. 2012-07. http://hdl.handle.net/10419/128949.

Oldakowski - R. K. - Roseman - C. C. (1986): The development of migration expectations: Changes throughout the lifecourse. Journal of Gerontology, 41(2), 290-295. https://doi.org/10.1093/geronj/41.2.290. 
Piore, M. J. (1979): Birds of Passage: Migrant Labor and Industrial Societies. Cambridge: Cambridge Univ. Press. https://www.popline.org/node/497102.

Ravenstein, E. G. (1889): The laws of migration. Journal of the Royal Statistical Society, 52(2), 241-305. http://www.jstor.org/stable/2979333?origin=JSTOR-pdf.

Schultz, T. W. (1983): Beruházás az emberi tőkébe. In Lengyel Gy. - Szántó Z. (szerk.): A gazdasági élet szociológiája. Budapest: Aula Kiadó, 36-47. https:// www.tankonyvtar.hu/hu/tartalom/tamop425/0010_2A_02_Lengyel_ Gyorgy-Szanto_Zoltan_szerk_A_gazdasagi_elet_szociologiaja/0010_2A_02_ Lengyel_Gyorgy-Szanto_Zoltan_szerk_A_gazdasagi_elet_szociologiaja.pdf.

Sell, R. R. - DeJong, G. F. (1978): Toward a motivational theory of migration decision making. Journal of Population and Environment, 1(4), 313-335. https:// link.springer.com/article/10.1007/BF00972555.

Sjaastad, L. A. (1962): Costs and returns of human migration. Journal of Political Economy, 70(5/2), 80-93. https://doi.org/10.1086/258726.

Stark, O. - Bloom, D. E. (1985): The new economics of labor migration. The American Economic Review, 75(2), 173-178. http://links.jstor.org/ sici?sici=0002-8282\%2819850 ... 0\%3B2-P\&origin=repec.

Wolpert, J. (1965): Behavioral aspects of the decision to migrate. Papers in Regional Science, 15(1), 159-169. https://doi.org/10.1111/j.1435-5597.1965.tb01320.x.

\section{Melléklet}

\section{A települések adottságait leíró indexek}

A T-Star adatbázisban 21 kategóriában szerepelnek adatok az ország összes településére 1990-től 2015-ig. Ezek közül oktatásra, munkanélküliségre, lakáshelyzetre, kultúrára, közmúvesítettségre, kereskedelemre, gazdaságra, egészségügyre és adózásra vonatkozóan összesen 22 változót választottunk ki a települések adottságainak és infrastruktúrájának a leírására. A változók kiválasztásakor fontos szempont volt, hogy az elemzési időszakra (2000-2014) éves gyakorisággal rendelkezésre álljanak megfigyelések. Amelyik változók természetes értékben voltak megadva, azoknak a logaritmusát használtuk (pl. kórházi ágyak száma, középiskolai tanárok száma, felsőoktatásban tanulók száma). Ahol az eredeti változó értéke ismert és nulla volt, a logaritmált értéket nullára cseréltük. Ezek után a változók információtartalmának sűrítése érdekében főkomponens-elemzést végeztünk. Ez hat faktorba vonta össze az információkat, melyeket tartalmuk alapján el is neveztünk (7. táblázat).

Az első faktor (1: Városi közszolgáltatások) a településeken az egy före eső kiskereskedelmi boltok számának logaritmusát, az egy főre eső vendéglátóhelyek számának logaritmusát, az egy főre eső kórházi ágyak számának logaritmusát, az egy főre eső bölcsődei férőhelyek számát és a múzeum létére vonatkozó dummy változót fog- 
lalja magában. Ehhez képest külön faktorba (4: Alapvető közszolgáltatások) kerültek az egy főre eső általános iskolai és óvodai férőhelyek, illetve a háziorvosok száma.

A 2., „Helyi gazdaság” faktorba került az egyéni és társas vállalkozások száma, az adófizetők aránya és az egy adófizetőre eső adóalap összege. Ettől elkülönült az 5. , „Munkaerőpiac” faktor, mely a tartós munkanélküliek arányát tartalmazza negatív előjellel és az ivóvízhálózatba bekötött lakások számát. Ez tehát egyfajta fordított előjelű deprivációs mutatóként értelmezhető.

A helyi vállalkozások nemzetgazdasági ág szerinti jellegét mutatja a 3., „Szolgáltató jelleg" faktor (melybe a mezőgazdasági vállalkozások aránya került negatív előjellel, míg a szolgáltatások aránya pozitívval, továbbá a gázfogyasztók aránya), illetve a 6., „Ipari jelleg” faktor, melybe a vállalkozások közül az iparhoz tartozók aránya került pozitív előjellel, míg a szolgáltatáshoz tartozóké negatívval.

7. táblázat: A településjellemzők korrelációs mátrixa

\begin{tabular}{|c|c|c|c|c|c|c|c|}
\hline \multirow[b]{2}{*}{ Eredeti változók } & \multicolumn{6}{|c|}{ Faktorok: } & \multirow[b]{2}{*}{$\begin{array}{l}\text { Magya- } \\
\text { rázatlan } \\
\text { hányad } \\
\end{array}$} \\
\hline & $\begin{array}{l}1 . \\
\text { Városi } \\
\text { szolg. }\end{array}$ & $\begin{array}{l}2 . \\
\text { Helyi } \\
\text { gazd. }\end{array}$ & $\begin{array}{c}3 . \\
\text { Szolg. } \\
\text { jelleg }\end{array}$ & $\begin{array}{c}4 . \\
\text { Alap } \\
\text { közsz. }\end{array}$ & \begin{tabular}{|c|}
5. \\
Munka- \\
erőpiac
\end{tabular} & $\begin{array}{c}6 . \\
\text { Ipari } \\
\text { jelleg }\end{array}$ & \\
\hline $\begin{array}{l}\text { Egy före eső társas vállalkozások száma } \\
(\mathrm{BT}+\mathrm{KFT})\end{array}$ & 0,0641 & 0,2698 & 0,1455 & $-0,0764$ & 0,0484 & $-0,0480$ &, 5981 \\
\hline Egy főre eső egyéni vállalkozások száma & -0.0314 & 0.6305 & -0.0643 & 0.0223 & -0.2502 & -0.0417 & .3303 \\
\hline $\begin{array}{l}\text { Ipar nemzetgazdasági ágaiban a társas } \\
\text { vállalkozások száma (összes társas vállal- } \\
\text { kozáson belül) }\end{array}$ & -0.0063 & -0.0205 & 0.0927 & -0.0141 & -0.0086 & 0.8144 & .04683 \\
\hline $\begin{array}{l}\text { Mezőgazdaság nemzetgazdasági ágaiban } \\
\text { a társas vállalkozások száma (összes társas } \\
\text { vállalkozáson belül) }\end{array}$ & 0.0191 & 0.0448 & -0.6483 & 0.0401 & 0.0162 & -0.1684 & 1834 \\
\hline $\begin{array}{l}\text { Szolgáltatások nemzetgazdasági ágaiban } \\
\text { a társas vállalkozások száma (összes társas } \\
\text { vállalkozáson belül) }\end{array}$ & -0.0121 & -0.0236 & 0.5105 & -0.0246 & -0.0075 & 192 & 0546 \\
\hline $\begin{array}{l}\text { Kiskereskedelmi boltok számának loga- } \\
\text { ritmusa }\end{array}$ & 0.3688 & -0.0701 & 0.1967 & 0.1494 & -0.0280 & 0.0428 & .1906 \\
\hline Vendéglátóhelyek számának logaritmusa & 0.3566 & -0.0088 & 0.1986 & 0.1144 & -0.0034 & 0.0290 & .197 \\
\hline Adófizetők arány & -0.0181 & 0.3751 & -0.0792 & 0.0138 & 0.3923 & -0.0011 & .2204 \\
\hline Egy före eső összev & 0.0198 & 0.4653 & 0.0359 & -0.0201 & 0.1864 & 0.0136 & .228 \\
\hline $\begin{array}{l}180 \text { napon túli álláskeresők aránya a } \\
\text { népességen belül }\end{array}$ & 0.0098 & 0.1282 & -0.0407 & -0.0023 & -0.6506 & 0.0131 & .3119 \\
\hline Egy főre eső háziorvosok száma & -0.0333 & 0.0573 & -0.0824 & 0.5362 & 0.0569 & -0.0428 & .4535 \\
\hline Kórházi ágyak számą & 0.4177 & -0.0273 & -0.1250 & -0.0730 & 0.0204 & -0.0491 & .3461 \\
\hline Egy főre eső bölcsődei férőhelyek száma & 0.2628 & 0.1538 & -0.0266 & -0.0218 & -0.1013 & 0.0292 & .6569 \\
\hline Egy főre eső óvodai férőhelyek száma & -0.0198 & 0.0458 & -0.0223 & 0.5333 & -0.0498 & -0.0162 & .4617 \\
\hline Egy főre eső ált. isk. pedagógusok száma & 0.0287 & -0.0586 & 0.0235 & 0.6029 & -0.0051 & 0.0204 & .2985 \\
\hline $\begin{array}{l}\text { Középisk. pedagógusok számának loga- } \\
\text { ritmusa }\end{array}$ & 0.4430 & -0.0021 & -0.0251 & -0.0483 & -0.0315 & 0.0006 & .2212 \\
\hline $\begin{array}{l}\text { Felsőoktatásban tanulók számának loga- } \\
\text { ritmusa }\end{array}$ & 0.3411 & 0.0064 & -0.1739 & -0.0813 & 0.0196 & -0.0605 & .5583 \\
\hline Könyvtár léte & 0.2394 & -0.1592 & -0.1103 & 0.0286 & 0.1651 & -0.0474 & .7308 \\
\hline Múzeum léte & 0.3250 & 0.0333 & -0.0304 & -0.0119 & -0.0445 & 0.0215 & .5763 \\
\hline Ivóvízhálózatba kapcsolt lakások aránya & -0.0069 & -0.0204 & -0.0761 & -0.0107 & 0.4958 & -0.0053 & .5992 \\
\hline $\begin{array}{l}\text { Csatornahálózatba kapcsolt lakások ará- } \\
\text { nya }\end{array}$ & 0.0 & 0.2755 & 0.1177 & -0.0019 & 0.1051 & 0.0949 & .5605 \\
\hline Egy lakásra eső gázfogyasztók száma & 0.0432 & 0.1096 & 0.3317 & 0.0634 & 0.1340 & 0.1028 & .4989 \\
\hline
\end{tabular}

